\title{
Effect of EGCG on bronchial epithelial cell premalignant lesions induced by cigarette smoke and on its CYP1A1 expression
}

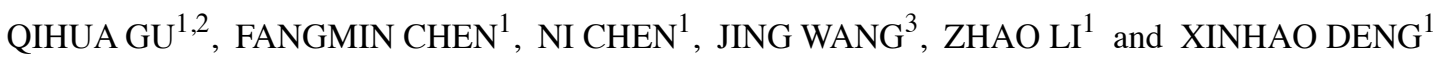 \\ ${ }^{1}$ Department of Respiratory Medicine, Xiangya Hospital Affiliated to Central South University; \\ ${ }^{2}$ Key Cite of National Clinical Research Center for Respiratory Disease; ${ }^{3}$ Department of Pathology, \\ Xiangya Hospital Affiliated to Central South University, Changsha, Hunan 410008, P.R. China
}

Received March 15, 2021; Accepted July 30, 2021

DOI: $10.3892 /$ ijmm.2021.5053

\begin{abstract}
Epigallocatechin-3-gallate(EGCG) has been demonstrated to exhibit anticancer effects; however, the mechanisms behind these are not yet clear. The objective of the present study was to assess the effect of EGCG on smoking-induced, precancerous, bronchial epithelial cell lesions and determine a potential protective mechanism. Human bronchial epithelial (HBE) cells were treated with cigarette smoke extract (CSE). Benzopyrene-DNA adducts were detected by immunofluorescence cytochemistry. Changes to microRNA (miRNA) expression levels were detected via microarray. The effects of EGCG on smoke-induced benzopyrene-DNA adduct formation and the subsequent change in miRNA expression were analyzed. Subsequently, the protective effect of EGCG on smoke inhalation-induced precancerous lesions was investigated. The expression levels of miRNA target genes were also analyzed. After CSE treatment, benzopyrene-DNA adducts appeared in HBE cells, along with a resultant change in miRNA expression. EGCG inhibited the effects of CSE exposure; benzopyrene-DNA adduct formation was reduced and miRNA expression changes were suppressed. In vivo, EGCG significantly reduced benzopyrene-DNA adduct formation and the subsequent development of precancerous lesions in rat lungs induced by cigarette smoke inhalation. Moreover, EGCG downregulated CYP1A1 overexpression, a target gene of multiple smoking-induced miRNAs, in rat lungs. EGCG may reduce the risk of lung cancer by downregulating the
\end{abstract}

Correspondence to: Dr Qihua Gu, Department of Respiratory Medicine, Xiangya Hospital Affiliated to Central South University, 87 Xiangya Road, Changsha, Hunan 410008, P.R. China

E-mail: guqh06@163.com

Abbreviations: BE, bronchial epithelial; EGCG, epigallocatechin-3-gallate; HBE, human bronchial epithelial; DMEM, Dulbecco's modified Eagle's medium; CSE, cigarette smoke extract

Key words: EGCG, lung cancer, premalignant lesion, cigarette smoke, CYP1A1 gene expression of the key gene CYP1A1, preventing the formation of smoking-induced benzopyrene-DNA adducts and alleviating smoking-induced bronchial epithelial dysplasia and heterogeneity.

\section{Introduction}

Although multiple risk factors have been linked to the development of lung cancer, cigarette smoke remains the leading cause of the disease (1-3). Tobacco contains multiple carcinogens; when these are inhaled into the lungs, bronchial epithelial (BE) cells are damaged which may initiate carcinogenesis. Carcinogens identified in tobacco exhibit a myriad of effects, ranging from DNA damage to metastasis promotion $(4,5)$. Cigarette smoke can cause damage to $\mathrm{BE}$ cells in a multitude of ways; much of this damage is usually corrected by cell self-repair mechanisms. However, this damage may build up and lead to the development of lung cancer. Smoking-induced human bronchial epithelial (HBE) cell carcinoma develops across multiple stages, including: DNA damage, BE hyperplasia, cell dysplasia, early carcinogenesis and finally invasive carcinoma development (6). In this multi-step carcinogenesis process, the formation of DNA adducts is considered to be a key cancer initiator (7). Therefore, the use of natural or synthetic agents in the prevention of smoking-induced, BE cell, DNA adduct formation, may play a role in the prevention of lung cancer. In lung cancer, cigarette smoke can also promote disease progression by altering the regulation of multiple genes including: TSPO, AP-2 $\alpha$ and EGF (8-11). Cigarette smoke has also been demonstrated to be involved in carcinogenesis through the modulation of key signaling pathways (12-14). Cigarette smoke also causes DNA methylation and site-specific histone modification (12-14). Cigarette smoke is involved in multiple processes that promote carcinogenesis; this renders combating its effects complicated (4). Due to this, a broad-spectrum anticancer agent may be the best approach for addressing cigarette smoke-mediated BE cell damage and subsequent carcinogenesis. The polyphenol epigallocatechin-3-gallate (EGCG), found in green tea, may be one such preventative, due to its array of anticancer properties.

EGCG is the most abundant and pharmacologically active polyphenol found in green tea (15). It is widely used due to its health benefits, including its chemoprevention and anticancer 
activity $(16,17)$. Whilst there is some dispute as to whether drinking green tea reduces the risk of lung cancer, experimental evidence has indicated that the polyphenols found in green tea may be protective against carcinogen-induced lung cancer (18-22). EGCG inhibits cell proliferation, migration, promotes apoptosis and inhibits the self-renewal capability of lung cancer stem-like cells; all of this may help it combat lung cancer (23-28). EGCG interacts with several signaling pathways to exude anticancer effects; these include: the JNK, PI3K/Akt, nuclear factor- $\kappa \mathrm{B}(\mathrm{NF}-\kappa \mathrm{B}), \mathrm{Wnt} / \beta$-catenin (29-32), ERK and ERK1/2/NEAT1 pathways $(33,34)$. The multi-pronged approach by which EGCG acts as a chemopreventive agent, (through the modulation of multiple signaling pathways and strong antioxidant effect) may be used to prevent BE cell lung carcinogenesis. However, the expression of various genes and signaling pathway activation are regulated by microRNA (miRNA) and epigenetic modifications. Molecular changes in lung cancer, such as the dysregulation of miRNA expression, have been linked to tobacco smoke (35). It is considered that EGCG affects the expression of various long non-coding RNAs and miRNAs in the cells, therefore affecting cell function (36). Moreover, EGCG treatment can modulate miRNAs that play a significant role in specific signaling pathways $(37,38)$. However, cigarettes contain thousands of chemical substances (39), including the carcinogen benzopyrene (40); there are several other carcinogens found in cigarette smoke, including: tobacco-specific nitrosamines (TSNA) (41), polycyclic aromatic hydrocarbons (PAH) $(39,40)$, aromatic amines, benzene, dioxin, catechol and carcinogenic quinones and hydrazine. The pathogenesis of smoking-related cancer formation is very complex; as such, elucidating protective mechanisms is equally complicated. Whether EGCG can prevent smoking-related lung cancer formation by reducing smoking-induced DNA damage in BE cells, as well as regulating the expression of miRNA in BE cells, remains to be investigated.

\section{Materials and methods}

Cell culture. HBE cells were purchased from the Xiangya Hospital Cell Bank (Central South University, Changsha, China). The base growth medium was Dulbecco's modified Eagle's medium (DMEM; HyClone; Cytiva). This was supplemented with fetal bovine serum(FBS; 10\%; Sigma-Aldrich; Merck KGaA) as well as penicillin/streptomycin $(100 \mathrm{U} / \mathrm{ml}$ penicillin $/ 100 \mu \mathrm{g} / \mathrm{ml}$ streptomycin). HBE cells had been stored in liquid nitrogen, before being thawed rapidly in a $37^{\circ} \mathrm{C}$ water bath. The cells were then dispensed into a $75 \mathrm{~cm}^{2}$ culture flask; the flask was then stored in an incubator at $5 \% \mathrm{CO}_{2}$. The growth medium was changed the following day.

Cigarette smoke extract (CSE) treatment and EGCG treatment. The original CSE solution was prepared using an aqueous medium; when smoke from burnt cigarettes passed through a sealed jar containing water, the toxic compounds contained in the smoke were collected in the solvent. During the experiment, the same cigarette brand was used and the original CSE solution was prepared on the day of the experiment. HBE cells were cultured at $37^{\circ} \mathrm{C}$ for $24 \mathrm{~h}$ with DMEM. Following this, the base medium was replaced with growth medium containing the final CSE. Flasks received growth media with CSE concentrations of 2.5, 5, 7.5, 10, 12.5 or $15 \%$. The original CSE solution was prepared with DMEM on the day of the experiment, with the final concentration determined by spectrophotometry. At 24, 48, and 72 h post-CSE treatment, an immunofluorescence assay was performed on the cells to detect benzopyrene-DNA adducts. The optimal time-point and CSE concentration for benzopyrene-DNA adduct formation was recorded. These parameters were then used for subsequent experiments. With reference to the literature and previous experiments $(26,27)$, the concentrations used for EGCG treatment were 0, 5, 10, 20 and $40 \mu \mathrm{M}$. A gene microarray technique was used to detect the differential miRNA expression profiles of the treated HBE cells.

Cell Counting Kit-8 (CCK-8) assay. A CCK-8 (MedChemExpress) assay was used to detect the survival rate of HBE cells. Cells were plated in 96-well plates at a density of $8 \times 10^{4}$ cells $/ \mathrm{ml}$ before CSE and EGCG treatments were performed. These cells were then cultured at $37^{\circ} \mathrm{C}$ in an incubator at $5 \% \mathrm{CO}_{2}$ for 24,48 and $72 \mathrm{~h}$. The treated medium was replaced with $100 \mu \mathrm{l}$ of the CCK-8 solution (CCK-8: PBS, 1:9). The plates were then wrapped in tin foil before being incubated at $37^{\circ} \mathrm{C}$ for a further $2 \mathrm{~h}$. The absorbance was then measured at $450 \mathrm{~nm}$ on an enzyme-labeling instrument. Each experiment was repeated 3 times.

Immunofluorescence cytochemistry. HBE cells were cultured on cell slides in 24-well plates. Following the treatment regimens, an immunofluorescence assay was performed. A specific BPDE-DNA adduct mouse monoclonal antibody (1:100; cat. no. sc-52625; Santa Cruz Biotechnology, Inc.) was used to detect DNA lesions in the HBE cells. The slide was incubated in a wet box at $4^{\circ} \mathrm{C}$ overnight. The cells were stained with DAPI $(10 \mu \mathrm{g} / \mathrm{ml}$; cat. no. D1306; Thermo Fisher Scientific, Inc.) at room temperature for $10 \mathrm{~min}$. The slides were then sealed with an anti-fluorescence quenching agent (containing 90\% glycerin; Thermo Fisher Scientific, Inc.) before images were captured under a fluorescence microscope (1:4 and 1:400).

Gene microarray assay and analysis. The treated HBE cells were washed with PBS. Cells were lysed with TRIzol reagent (Invitrogen; Thermo Fisher Scientific, Inc.). Total RNA was extracted using a Mini miRNA extraction kit (cat. no. 217004; Qiagen China Co., Ltd.). RNA integrity was assessed using RNA denaturation electrophoresis (Bioanalyzer 2100; Agilent). miRNA microarray hybridization experiments and data collection were performed by the Wuhan Google Biotechnology Co., Ltd. A miRNA microarray hybridization chip (cat. no. G4474A; Agilent Technologies, Inc.) was scanned using an Agilent Microarray Scanner. The featured extraction software version 10.7.1.1 (Agilent Scan Control software) was used to collect and analyze data. The fold change of differentially screened miRNA was at least two-fold compared with the control group. Functional changes to miRNA expression levels following EGCG treatment were determined by comparative analysis. Furthermore, bioinformatics technology was used to predict the target genes and signaling pathways affected by EGCG treatment. The miRNA target gene 
prediction softwares, miRDB (http://mirdb.org/miRDB), Diana microT v3.0 (http://diana.cslab.ece.ntua.gr/microT) and TargetScan 3.0 (http://www.targetscan.org/), were used to predict the target genes of the selected miRNA. Targeted signaling pathways were predicted by the signaling pathway analysis software 'Ingenuity Pathway Analysis' (http://www. ingenuity.com). The most important miRNA was further validated in tissue samples by fluorescence in situ hybridization. The experiment was carried out according to the instructions of a FAM-Labeled Probe Detection kit (Wuhan Servicebio Technology Co., Ltd.). The sequence of the gene-specific oligonucleotide probe was 5'-FAM-ACAGGCACCCCACTCCAC AGA-FAM-3' for miRNA-7114-5p. The sections were dewaxed with xylene for $15 \mathrm{~min}$. For RNA retrieval, the sections were placed into boiling water for $15 \mathrm{~min}$ and cooled naturally. Subsequently, the sections were digested with protease $\mathrm{K}$ $\left(20 \mu \mathrm{g} / \mathrm{ml}\right.$; Wuhan Servicebio Technology Co., Ltd.) at $37^{\circ} \mathrm{C}$ for $30 \mathrm{~min}$. Following incubation with pre-hybridization solution at $37^{\circ} \mathrm{C}$ for $1 \mathrm{~h}$, the sections were treated with probe miRNA-7214-5p hybridization solution $(8 \mathrm{ng} / \mu \mathrm{l})$ and placed in an incubator at $37^{\circ} \mathrm{C}$ overnight. Tissue sections were stained with DAPI $(10 \mu \mathrm{g} / \mathrm{ml})$, incubated in darkness for $8 \mathrm{~min}$, and sealed with anti-fluorescence quenching agent. The images were collected under a fluorescence microscope.

Immunohistochemical analysis of patient tissues. Non-small cell lung cancer specimens and adjacent tissues, atypical hyperplasia, and chronic inflammatory tissues were collected. Tissue samples were collected from 30 patients, including 19 males and 11 females, aged 37 to 68 years. This research protocol was approved by the Medical Ethics Committee of Xiangya Hospital of Central South University (approval no. 201703133), and paraffin-embedded tissue samples were selected from the specimen bank of the Department of Pathology of Xiangya Hospital. These samples were preserved and paraffin-embossed after surgical treatment at the Department of Thoracic Surgery of Xiangya Hospital from May 2018 to October 2019. All patients provided written informed consent before surgery. Retrospective investigation of clinical data revealed that all patients with non-small cell lung cancer had a lung mass or nodule which was found by enhanced CT examination, and were confirmed as non-small cell lung cancer by postoperative pathological diagnosis. Para-carcinoma tissue was defined as lung tissue removed from the margin of lung cancer tissue of more than $20 \mathrm{~mm}$. The patients with atypical hyperplasia or pulmonary inflammation were those who had a lung mass or pulmonary nodule suspected diagnosis such as lung cancer (possibly lung cancer) by enhanced CT scan before operation and confirmed atypical hyperplasia or pulmonary inflammation by pathological diagnosis after surgical resection. Continuous $4-\mu \mathrm{m}$ thick tissue sections were sliced. Immunohistochemistry was used to detect protein expression in different lung tissues. For immunohistochemical protein detection, xylene was used to dewax the paraffin sections. For antigen retrieval, the sections were placed into a sodium citrate buffer $(\mathrm{pH}$ 6.0) and heated in a microwave for 2 min before being placed in a water bath $\left(98^{\circ} \mathrm{C}\right)$, for a further $20 \mathrm{~min}$. The expression levels of NF- $\mathrm{\kappa B}$ $(1: 200)$, transforming growth factor (TGF)- $\beta(1: 200)$ and
CYP1A1 (1:200) proteins were detected by their respective specific rabbit-antibodies: product no. ADI-KAS-TF110-D (Enzo Life Sciences, Inc.); and cat. nos. MBS462142 and MBS127670; MyBioSource, Inc.). The slides were incubated in a wet box at $4^{\circ} \mathrm{C}$ overnight. Tissue known to express the target protein was used as a positive control, while tissue known to have an absence of the protein was used as a negative control. DAB staining (at room temperature for $15 \mathrm{~min}$ ) was used to assess the results. A scoring system from 0-3 was devised; unstained cells scored 0 , mild yellow staining scored 1, strong yellow staining scored 2 and brown staining scored 3 . The percentage of cells positively stained was also scored; $<5 \%$ was 0 points, $5-25 \%$ was 1 point, $26-50 \%$ was 2 points, and $>50 \%$ was 3 points. These scores were then multiplied to provide an overall grading; a score of 0-1 was negative (-), 2-3 was weakly positive $(+), 4-6$ was positive (++) and a score of 6-9 was strongly positive (+++).

Animals and treatments. Female Sprague Dawley (SD) rats, aged 6-8 weeks and weighing 180-200 g, were purchased from the Department of Experimental Animals (Central South University, Changsha, China). A total of 60 rats were randomly divided into three groups. Animals were caged in groups of five. The rats were kept at room temperature $\left(24 \pm 2^{\circ} \mathrm{C}\right)$, $50 \%$ humidity and in a 12-h light/dark cycle with adequate food and water supply. The control and cigarette smoke (CS) treatment groups were administered normal drinking water, while the EGCG group received water supplemented with EGCG $(0.3 \%)(13,42)$. The EGCG solution was prepared and changed daily. Following 2 weeks of drinking the solution, the rats inhaled CS. All rats in the CS +/- EGCG treatment groups were exposed to 90 min of CS a day, 5 days a week (43-45). The rats were treated in a transparent glass cage. A total of 10 cigarettes were lit at a time. In each round of exposure, the rats were treated with passive smoke for $15 \mathrm{~min}$, the sealed cover of the cage was then opened and the rats were allowed to breathe 'clean' air for $15 \mathrm{~min}$. During the next round of exposure, rats were passively exposed to smoke for $90 \mathrm{~min}$, with close attention paid to the activity of the rats during this period. Following this exposure, smoking treatment was immediately discontinued if there was evidence of breathing difficulties (rapid breathing, salivation, and cyanosis). On the 4,8,12 and 16th weekend following the introduction of CS, 5 rats from each treatment group were sacrificed. Rats received an intraperitoneal injection of a chloral hydrate solution $(300 \mathrm{mg} / \mathrm{kg})$, before being sacrificed under anesthesia. In brief, after weighing the rats with an electronic balance, the required $10 \%$ chloral hydrate solution was calculated. The anesthetic solution was extracted with a syringe and injected into the abdominal cavity of the rats. The rats quickly lost consciousness after the injection, and none of the rats exhibited signs of peritonitis, pain or discomfort. After the breathing of the rat became slow and weak and it did not respond to stimulation, the rat was sacrificed by exsanguination from the carotid artery under the conditions of unconsciousness and painlessness. All of the animals were treated humanely and in compliance with the Animal Welfare Act of America. The experiment was approved (approval no. 201703133) by the Ethics Department of Xiangya Hospital, Central South University (Changsha, China). 
Histopathological examination. Tissue from each lung of the treated rats was obtained, completely immersed in $4 \%$ paraformaldehyde at room temperature, fixed for $24 \mathrm{~h}$. This was then transferred to a $0.2 \%$ sodium azide solution at room temperature, and tissue continued to be fixed for $24 \mathrm{~h}$ before being embedded in paraffin. Each lobe was sectioned in 5 consecutive slices at a thickness of $5 \mu \mathrm{m}$. Each section was stained with $0.5 \%$ hematoxylin for $10 \mathrm{~min}$ and $0.5 \%$ eosin for $3 \mathrm{~min}$ and analysis was performed independently by two pathologists.

Immunohistochemical analysis of rat tissues. Prepared rat lung sections were dewaxed in xylene and then alcohol. These sections were then placed in a $0.1 \mathrm{~mol} / \mathrm{l}$ citric acid buffer solution $(\mathrm{pH}=6)$ and microwaved for $20 \mathrm{~min}$ to retrieve antigens (microwave oven PM100). The tissue was blocked using $10 \%$ goat serum (Beijing Zhongshan Jinqiao Biotechnology, Inc.) at room temperature for $1 \mathrm{~h}$ in a wet box. Staining for benzopyrene-DNA adducts in the rat lung samples was performed using an anti-BPDE-adduct mouse monoclonal antibody (1:100) for $1 \mathrm{~h}$ at room temperature. The sections were then rinsed and incubated with a secondary goat anti-mouse antibody (1:200; LS-C56298; LifeSpan BioSciences, Inc.) for $60 \mathrm{~min}$ at room temperature. Positive and negative samples, where benzopyrene-DNA adducts were present or absent, were used as controls. After the experiment was completed, the glass slides were sealed with an anti-fluorescence quenching agent. The benzopyrene-DNA adducts were observed and images were captured using a fluorescence microscope, before the average optical density was assessed by ImageJ software v1.8.0 (National Institutes of Health).

Reverse transcription-quantitative $(R T-q) P C R$. Total RNA of rat lung tissue was extracted according to the Direct-zol ${ }^{\mathrm{TM}}$ RNA MiniPrep Quick Protocol (Zymo Research Corp). RNA was reverse transcribed to cDNA using the High Capacity cDNA Reverse Transcription Kit (cat. no. 4368813; Applied Biosystems; Thermo Fisher Scientific, Inc.). A total of $50-\mu 1$ reaction volumes, containing $500 \mathrm{ng}$ of sample RNA, were prepared for cDNA amplification. Using a Bio-Rad MyCycler ${ }^{\mathrm{TM}}$, the reaction was carried out at $25^{\circ} \mathrm{C}$ for $10 \mathrm{~min}$, $37^{\circ} \mathrm{C}$ for $120 \mathrm{~min}$ and held at $4^{\circ} \mathrm{C}$ upon completion. The GAPDH gene was amplified as a positive control, an RT negative sample was produced using the same reaction mixture without reverse transcriptase. The cDNA products were diluted at 1:10 for use in qPCR. qPCR was performed using an ABI Quantstudio ${ }^{\mathrm{TM}} 3$ Real-Time PCR System, with SYBR Green Master Mix (Bio-Rad Laboratories, Inc.). Primers were synthesized by Shanghai Biotechnology Co., Ltd. and were as follows: NF- $\kappa$ B forward, 5'-GGCTTCTATGAGGCTGAA CTCTGC-3' and reverse, 5'-CTTGCTCCAGGTCTCGCT TCTTC-3'; CYP1A1 forward, 5'-CAGGACAGGAGGCTG GACGAG-3' and reverse, 5'-ACCAGGTACATGAGGCTC CAAGAG-3'; GAPDH forward, 5'-GACATGCCGCCTGGA GAAAC-3' and reverse, 5'-AGCCCAGGATGCCCTTTA GT-3'. The q-PCR reactions were carried out at $94^{\circ} \mathrm{C}$ initial denaturation for $2 \mathrm{~min}$; 40 of cycles at $94^{\circ} \mathrm{C}$ denaturation for $15 \mathrm{sec}, 60^{\circ} \mathrm{C}$ annealing, elongation and fluorescence was read for $1 \mathrm{~min}$; and $60^{\circ} \mathrm{C}$ final extension for $4 \mathrm{~min}$. All data were analyzed using the $2^{-\Delta \Delta \mathrm{Cq}}$ method (46).
Western blot analysis. Rat lung tissue was collected to determine the level of $\mathrm{NF}-\kappa \mathrm{B}$ and CYP1A1 protein expression. Lung tissue was washed twice with cold TBS and crushed in a $1.5-\mathrm{ml}$ homogenate tube, before being placed on ice and suspended in RIPA buffer (cat. no. G2002; Wuhan Servicebio Technology Co., Ltd.) with protein inhibitor. The mixture was placed in an ice-bath for $30 \mathrm{~min}$, centrifuged $13,000 \mathrm{x}$ g at $4^{\circ} \mathrm{C}$ for $15 \mathrm{~min}$, before the supernatant was removed in a clean tube and stored at $-80^{\circ} \mathrm{C}$. To perform the western blot analysis, $16 \mu \mathrm{l}$ of sample containing $150 \mu \mathrm{g}$ of protein was loaded along with $1.6 \mu 1$ of 10X SDS buffer and $4 \mu 1$ of SDS buffer per well of a $10 \%$ SDS-PAGE gel, then electrophoresis was performed at $80 \mathrm{~V}$ for $100 \mathrm{~min}$. Electrophoresis was stopped and the protein on the gel was transferred to a nitrocellulose membrane at $60 \mathrm{~V}$ for $120 \mathrm{~min}$. The membrane was then blocked with $5 \%$ fat-free milk for $1 \mathrm{~h}$ at room temperature. The membrane was then incubated with mouse specific NF-кB (1:1,000; cat. no. GB11142; Wuhan Servicebio Technology Co., Ltd.) and CYP1A1 (1:1,000; cat. no. sc-101828; Santa Cruz Biotechnology, Inc.) antibodies overnight at $4^{\circ} \mathrm{C}$. Next, the membrane was washed three times with TBS-T (0.1\% Tween-20) buffer for $10 \mathrm{~min}$. The membrane was then incubated with a goat anti-rat secondary antibody (1:3,000; GB23302; Wuhan Servicebio Technology Co., Ltd.) for $2 \mathrm{~h}$ at room temperature, before the washing step was repeated. Finally, the blot was developed using a prepared A (luminol) and B (hydrogen peroxide), 1:1 reagent mix and incubated at room temperature for $5 \mathrm{~min}$, before images were captured using a ChemiDoc ${ }^{\mathrm{TM}} \mathrm{XRS}+$ system with Image $\mathrm{Lab}^{\mathrm{TM}}$ Software V6.0 (Bio-Rad Laboratories, Inc.).

Statistical analysis. The data are presented as the mean \pm SD of three repeats. SPSS 24.0 (IBM Corp.) statistical software was used to analyze the data. A paired Student's t-test was used for comparison between two groups. One-way analysis of variance (ANOVA) was used for comparison between multiple groups. The pairwise comparisons among the multiple groups were conducted using Tukey's post hoc test. All statistics were bilateral. The test level was set as $\alpha=0.05$, and $\mathrm{P}<0.05$ was considered to indicate a statistically significant difference. GraphPad Prism v. 6 (GraphPad Software, Inc.) was used to create all the graphs.

\section{Results}

HBE cell damage by CSE. After CSE treatment, two types of damage occurred in the HBE cells. Acute toxicity was associated with a decreased survival of HBE cells. When the CSE concentration reached $5 \%$, the survival rate of $\mathrm{HBE}$ cells was $<50 \%$. The effect of CSE on HBE cell survival was revealed to be time and concentration-dependent (Fig. 1). CSE-induced DNA damage, was observed in the surviving HBE cells. In addition, benzopyrene-DNA adducts were detected in HBE cells after $24 \mathrm{~h}$ of 5\% CSE treatment (Fig. 1).

Effect of EGCG on HBE cell damage induced by CSE. HBE cells were treated with different concentrations of EGCG $(0,5,10,20$ and $40 \mu \mathrm{M})$. The cell survival rate between each treatment group and the control was not significantly different $(\mathrm{P}>0.05)$. No apparent cytotoxicity was observed at any concentration of EGCG (Fig. 2). Compared with the CSE only 
A
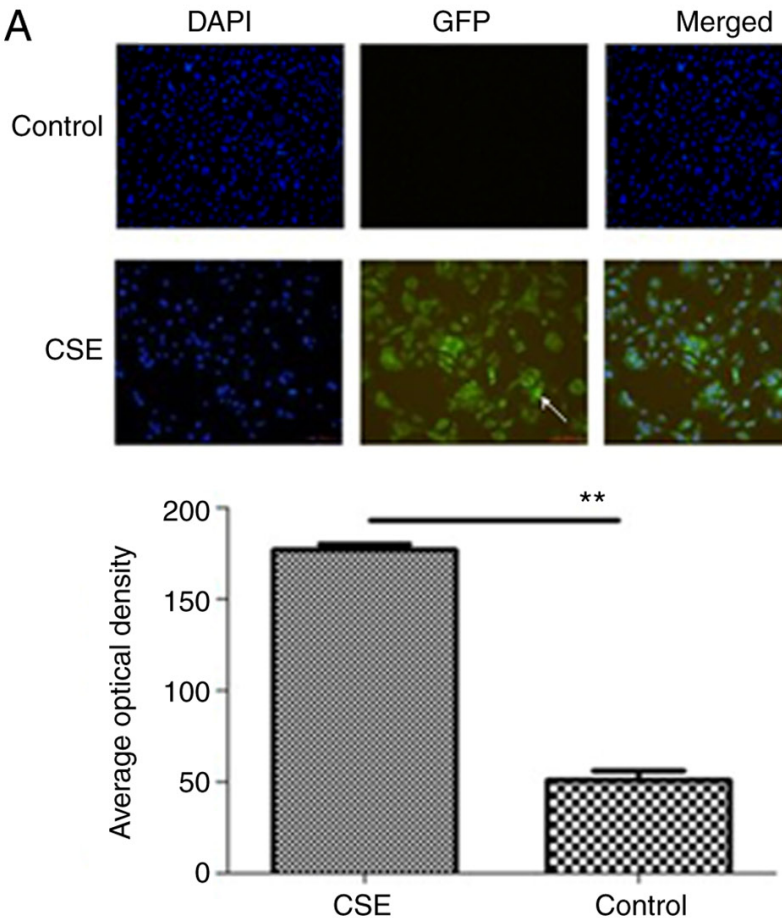

B
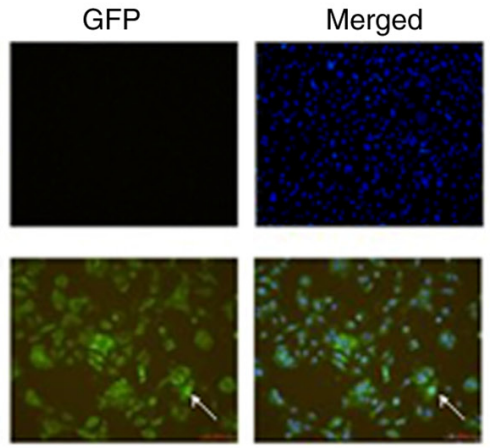

Control
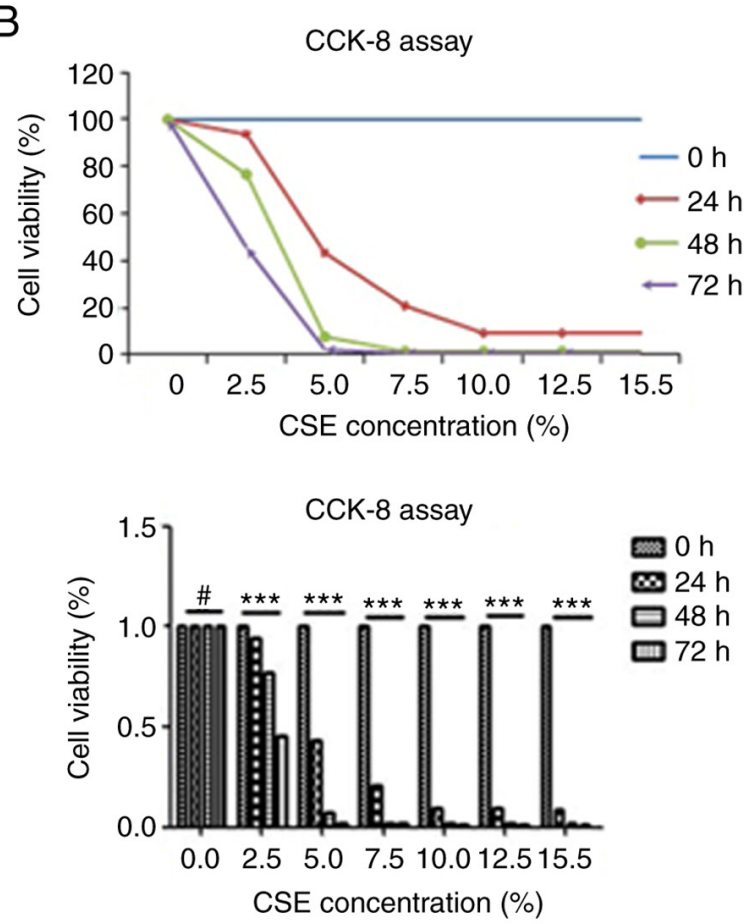

Figure 1. HBE cell damage reactions post CSE treatment. (A) Immunofluorescence assay for benzopyrene-DNA adduct detection. In panel GFP and panel Merged (DAPI Merged with GFP), immunofluorescence denotes a benzopyrene-DNA adduct in cells. There was clear fluorescence of benzopyrene-DNA adducts in HBE cells after $24 \mathrm{~h}$ of $5 \%$ CSE treatment. No obvious benzopyrene-DNA adducts were detected in the control. The difference was statistically significant. (B) A Cell Counting Kit-8 assay for CSE concentration-gradient treatment experiment. The absorbance was measured at 450 nm. Acute toxicity was associated with a decreased survival of HBE cells. The graph revealed that the survival rate of HBE cells decreased as the concentration of CSE increased. The effect of CSE on HBE cell survival was revealed to be time and concentration-dependent. When the CSE concentration reached 5\%, the survival rate of HBE cells was $<50 \%$ after 24 h of $5 \%$ CSE treatment. ${ }^{*} \mathrm{P}>0.05,{ }^{* *} \mathrm{P}<0.01$ and ${ }^{* * *} \mathrm{P}<0.001$. HBE, human bronchial epithelial; CSE, cigarette smoke extract; GFP, green fluorescent protein.

treatment group, the $\mathrm{HBE}$ cells treated with 5\% CSE+EGCG revealed a significantly higher survival rate. This indicated that EGCG protected HBE cells against CSE-mediated acute injury. The immunofluorescence assay revealed that $\mathrm{HBE}$ cells treated with CSE+EGCG formed less benzopyrene-DNA adducts than the CSE group. EGCG significantly reduced the formation of benzopyrene-DNA adducts induced by CSE exposure (Fig. 2).

miRNA differential expression. HBE cell miRNA expression profiles were detected by microarray assay. The miRNA expression profiles of HBE cells treated with CSE were significantly different when compared with the expression profiles of untreated HBE cells. The expression of multiple miRNAs was upregulated (Table I), while the expression of several other miRNAs was downregulated (Table II). When HBE cells were treated with CSE and EGCG, the miRNA expression profile was significantly different compared with treatment with CSE only. EGCG treatment inhibited the CSE-mediated upregulation of several miRNAs (Table III). Moreover, new miRNAs were upregulated following EGCG treatment (Table IV).

These differentially expressed miRNAs were initially screened in HBE cells treated with EGCG and CSE. Non-small cell lung cancer, para-cancer, atypical hyperplasia and inflammatory tissues were collected and evaluated. miRNA levels were assessed by fluorescence in situ hybridization. This was performed to understand the clinical significance of the miRNA expression changes observed in the CSE-treated HBE cells. For example, miRNA-7114-5p was highly expressed in non-small cell lung cancer and atypical hyperplasia, with low expression in para-carcinoma and inflammatory tissues (Fig. 3). The difference was statistically significant $(\mathrm{P}<0.05)$.

Expression levels of TGF- $\beta, C Y P 1 A 1$ and $N F-\kappa B$ in non-small cell lung carcinoma tissues. Based on the original data, the functional miRNAs regulated by EGCG were screened using functional acquisition/loss analysis. A potential miRNA target gene had to be predicted by at least two predictive software (47-50). Targeted signaling pathways were predicted by the signal pathway analysis software 'Ingenuity Pathway Analysis' (http://www.ingenuity.com) (51,52). The bioinformatic analysis revealed that the CSE-mediated damage response of HBE cells involved multiple signaling pathways. The 'TGF- $\beta$ signaling pathway', 'NOD-like receptor signaling pathway', 'cytochrome P450 pathway', 'p53 signaling pathway' and 'ErbB signaling pathway' were all targeted. The results of signaling pathway prediction were compared between the EGCG-treated group and the non-EGCG treated groups (Fig. S1). The protective effect of EGCG against CSE-induced damage was mediated by the NF- $\mathrm{B}$, TGF- $\beta$, p53, Bcl-2 and CYP signaling pathways. Conversely, in clinical pathological samples, TGF- $\beta$ and CYP1A1 were revealed to be overexpressed in non-small cell lung carcinoma tissue and in atypical hyperplasia tissue, with low expression in para-lung carcinoma and chronic inflammatory lung tissue. $\mathrm{NF}-\kappa \mathrm{B}$, on the other hand, had low expression levels in non-small cell 
A
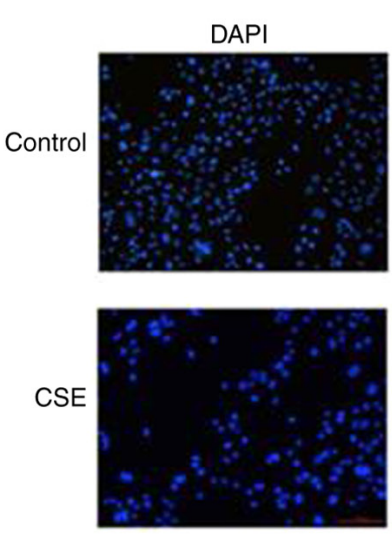

CSE+EGCG

$$
\begin{aligned}
& \frac{7}{0} \\
& \frac{1}{0} \\
& \frac{0}{0} \\
& \frac{0}{0} \\
& \frac{0}{0} \\
& \frac{0}{0} \\
& \frac{7}{10} \\
& \frac{1}{4}
\end{aligned}
$$
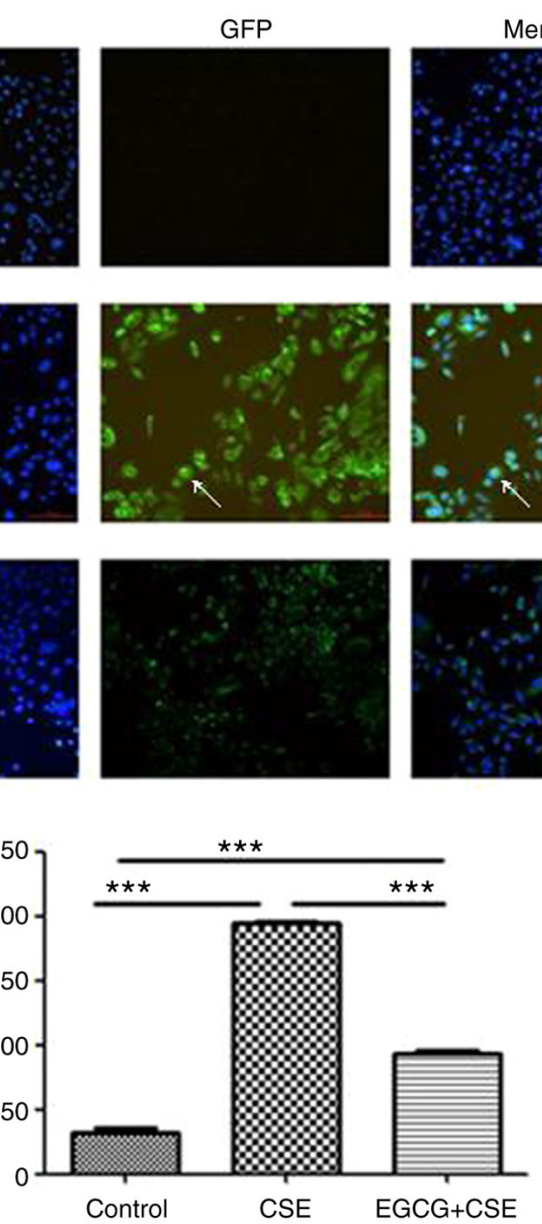

B
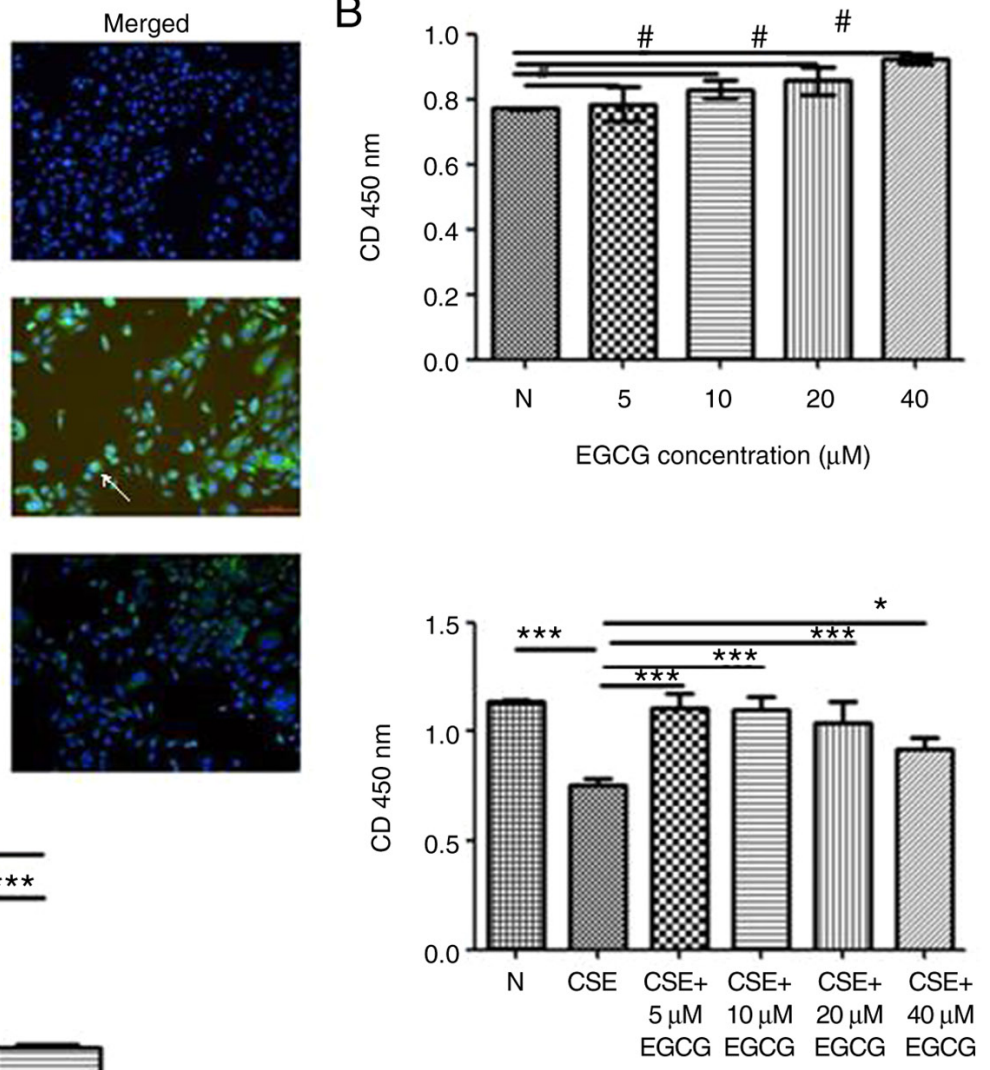

Figure 2. Effect of EGCG on HBE cell damage induced by CSE. (A) In panel GFP and panel Merged (DAPI Merged with GFP), immunofluorescence revealed a benzopyrene-DNA adduct in cells. In the control cells, there was no evidence of benzopyrene-DNA adducts. After CSE treatment, benzopyrene-DNA adducts were detected in the nucleus of HBE cells. Cells treated with CSE+EGCG had significantly less benzopyrene-DNA adducts than cells treated with CSE alone. (B) HBE cells were treated with different concentrations of $\operatorname{EGCG}(0,5,10,20$ and $40 \mu \mathrm{M})$. The cell survival rate between each treatment group and the control was not significantly different. No apparent cytotoxicity was observed at any concentration of EGCG. Compared with the CSE only treatment group, the HBE cells treated with 5\% CSE+EGCG revealed a significantly higher survival rate. ${ }^{*} \mathrm{P}>0.05,{ }^{*} \mathrm{P}<0.05$ and ${ }^{* * * *} \mathrm{P}<0.001$. EGCG, epigallocatechin-3-gallate; HBE, human bronchial epithelial; CSE, cigarette smoke extract; GFP, green fluorescent protein.

lung carcinoma and atypical hyperplasia tissue, while being overexpressed in para-lung carcinoma and chronic inflammatory lung tissue (Fig. 4).

Bronchial epithelium lesions induced by CSE in rats and protection of EGCG. As in the previous experiment, the amount of water the rats drank varied slightly across the different experimental stages. However, the water consumed by the two groups of rats was roughly equal, with the water consumed by each rat averaging between 20 and $30 \mathrm{ml}$. Other conditions, such as food consumption, body weight and activity levels of the rats, were not significantly different between the EGCG-treated group and the EGCG-non-treated group. In the animal experiment, the rat lungs were stained with H\&E before being assessed by two independent pathologists. After 4 weeks of passive smoke inhalation to the end of the experiment, chronic pulmonary inflammation and BE hyperplasia was evident. EGCG treatment significantly alleviated these CSE-induced lesions. There was no evidence of disease in the lungs of the control group (Fig. 5).
Effect of EGCG on CSE-induced benzopyrene-DNA adduct formation in rat lungs. This experiment used immunofluorescence histochemistry to detect pulmonary benzopyrene-DNA adducts induced by CSE. After four weeks, there was fluorescence; this indicated the presence of benzopyrene-DNA adducts in the lung tissue of rats treated with CSE. The level of fluorescence increased gradually until the experimental endpoint. This demonstrated an increase in the number of benzo pyrene-DNA adducts in the lung tissue and BE cells of CSE-treated rats. Rats treated with CSE+EGCG revealed markedly weaker staining, suggesting they developed significantly fewer benzopyrene-DNA adducts compared with the CSE only treatment group. The control group developed no benzopyrene-DNA adducts across the full experiment (Fig. 6).

Effects of EGCG on CYPIAl and NF- $\kappa B$ mRNA expression induced by CSE in rat lung tissues. The mRNA expression levels of the target genes CYP1A1 and NF- $\mathrm{B}$ were detected by RT-qPCR. CYP1A1 mRNA expression in the lung tissue of rats exposed to CS began to increase after four weeks of 
Table I. Upregulated miRNA expression in human bronchial epithelial cells following cigarette smoke extract treatment.

\begin{tabular}{|c|c|c|c|}
\hline Systematic name & active_sequence & miRBase_accession_No & Fold change \\
\hline hsa-miR-6131 & CACTCCCATCTGACC & MIMAT0024615 & 7.372937839 \\
\hline hsa-miR-5581-5p & ТСТССАТTТСТССТGGA & MIMAT0022275 & 7.227041457 \\
\hline hsa-miR-4716-3p & TCTCCATGTTTCСТTCC & MIMAT0019827 & 6.90081197 \\
\hline hsa-miR-3198 & TCTCCATTCCCCAGG & MIMAT0015083 & 6.316905823 \\
\hline hsa-miR-1305 & TCTCTCCCATTAGAGTTGA & MIMAT0005893 & 5.62008685 \\
\hline hsa-miR-6717-5p & ТСТСТАСАТССССАСАТС & MIMAT0025846 & 5.504413227 \\
\hline hsa-miR-6767-5p & TCTCCATGTGTCCCTG & MIMAT0027434 & 5.357791135 \\
\hline hsa-miR-4713-3p & TTCTCCCACTGTCTGG & MIMAT0019821 & 4.86793705 \\
\hline hsa-miR-6734-5p & ТСТССАССТСАТТСТСС & MIMAT0027369 & 4.702717565 \\
\hline hsa-miR-6740-5p & ТСТССТСТСТССАТССС & MIMAT0027381 & 4.505579757 \\
\hline hsa-miR-6879-5p & СТСТСССАССТТССС & MIMAT0027658 & 4.294047462 \\
\hline hsa-miR-6780b-5p & TCTTCCCTGCCAAGC & MIMAT0027572 & 3.974158682 \\
\hline hsa-miR-6875-5p & TCTCCTGTCCTGGGT & MIMAT0027650 & 3.699151613 \\
\hline hsa-miR-6124 & ТССТСССССТТССТТ & MIMAT0024597 & 3.644386611 \\
\hline hsa-miR-6127 & ССТСССАСССАСТС & MIMAT0024610 & 3.329050106 \\
\hline hsa-miR-4442 & ССТСССТСТTGTCCG & MIMAT0018960 & 3.290982071 \\
\hline hsa-miR-575 & GCTCCTGTCCAACTGGCT & MIMAT0003240 & 3.112871166 \\
\hline hsa-miR-4788 & GCCTCCCTTAGCTGG & MIMAT0019958 & 2.802568783 \\
\hline hsa-miR-6763-5p & CTCCCCAGCCACTC & MIMAT0027426 & 2.635624935 \\
\hline hsa-miR-5739 & GCTCCCCATTCTCTCT & MIMAT0023116 & 2.48844758 \\
\hline hsa-miR-6165 & СТССССТСАССТСС & MIMAT0024782 & 2.431995318 \\
\hline hsa-miR-7641 & GCTTAGCTTCCGAGATC & MIMAT0029782 & 2.360662434 \\
\hline hsa-miR-4499 & TCССТССТСТСАGTCT & MIMAT0019035 & 2.276882434 \\
\hline hsa-miR-4653-3p & TCTCCAAGCAACCCTT & MIMAT0019719 & 2.249377984 \\
\hline hsa-miR-1275 & GACAGCCTCTCCCC & MIMAT0005929 & 2.194037944 \\
\hline hsa-miR-7114-5p & ACAGGCACCCCACT & MIMAT0028125 & 2.118378937 \\
\hline hsa-miR-6826-5p & AGGTCCCACCTCTTTC & MIMAT0027552 & 2.115317566 \\
\hline hsa-miR-6749-5p & GCTCCCCCAACCC & MIMAT0027398 & 2.052827758 \\
\hline hsa-miR-197-5p & ССТCССACTGCCC & MIMAT0022691 & 2.011052693 \\
\hline
\end{tabular}

hsa, homo sapiens; miRNA or miR, microRNA.

exposure. There was a gradual increase in the expression of mRNA across the full experiment, with the highest expression levels after 16 weeks of CS exposure. The mRNA level of CYP1A1was significantly lower in the EGCG-treated group across all time-points, when compared with the smoking only group (Fig. 7) $(\mathrm{P}<0.05)$. The $\mathrm{NF}-\kappa \mathrm{B}$ expression levels, following CS exposure, differed from that of CYP1A1. The level of $N F-\kappa B$ mRNA expression was increased after the fourth week. NF- $\kappa \mathrm{B}$ expression was highest after 8 weeks of CS exposure. Following this, the expression level decreased. This pattern was also mirrored in the rats exposed to CS and treated with EGCG. At four and eight weeks, EGCG intervention led to significantly lower $\mathrm{NF}-\kappa \mathrm{B}$ expression compared with rats exposed to CS only (Fig. 7) $(\mathrm{P}<0.01)$.

Effects of EGCG on CYPIA1, NF- $\kappa B$ protein expression induced by CSE in rat lung tissues. Western blotting was used to detect the protein expression of CYP1A1 and NF- $\kappa$ B. Both CYPA1 and NF- $\kappa$ B proteins were at low levels in untreated rat lung tissue. After four weeks of treatment, CYP1A1 and NF- $\kappa \mathrm{B}$ protein expression levels were increased in lung tissue treated with CS. Over the 16-week observation period, CYP1A1 protein expression levels increased in the lungs of rats treated with CS. Unlike CYP1A1, NF- $\kappa \mathrm{B}$ protein expression in the lung tissues of rats treated with CS started to decrease after twelve weeks. Over the course of 16 weeks, EGCG downregulated the overexpression of CYP1A1 and $\mathrm{NF}-\kappa \mathrm{B}$ proteins in lung tissues of rats treated with CS (Fig. 8).

\section{Discussion}

EGCG inhibits benzopyrene-DNA adducts and alleviates smoking-induced precancerous lesions in bronchial epithelium. Lung cancer is a chronic disease that does not develop immediately upon exposure to a carcinogen $(53,54)$, with chronic exposure to CS significantly increasing the risk of developing disease. It may take a long time between the initial carcinogen exposure to the onset of lung cancer (6). Tobacco contains carcinogenic substances such as benzopyrene. After smoking, benzopyrene binds to the DNA of epithelial cells 
Table II. Downregulated miRNA expression in human bronchial epithelial cells following cigarette smoke extract treatment.

\begin{tabular}{|c|c|c|c|}
\hline Systematic name & active_sequence & miRBase_accession_No & Fold change \\
\hline hsa-miR-185-5p & TCAGGAACTGCCTTTCT & MIMAT0000455 & 0.494826228 \\
\hline hsa-miR-200b-5p & TCCAATGCTGCCCAG & MIMAT0004571 & 0.494208987 \\
\hline hsa-miR-1304-3p & GGGGTTCGAGGCT & MIMAT0022720 & 0.491609208 \\
\hline hsa-miR-4291 & AGCTGTTCCTGCTGAA & MIMAT0016922 & 0.486833224 \\
\hline hsa-miR-3162-3p & TGGGGAGTGGAGGG & MIMAT0019213 & 0.486455419 \\
\hline hsa-miR-10b-5p & CACAAATTCGGTTCTACAGGG & MIMAT0000254 & 0.480239071 \\
\hline hsa-miR-6737-3p & CTGGGTAGGGGTGA & MIMAT0027376 & 0.475216109 \\
\hline hsa-miR-8485 & ATACGTGTGTGTGTGTG & MIMAT0033692 & 0.469232286 \\
\hline hsa-miR-4649-3p & TGGGGAGAGGCAGG & MIMAT0019712 & 0.46559046 \\
\hline hsa-miR-6132 & TGCAATCCCCAGCC & MIMAT0024616 & 0.447294549 \\
\hline hsa-miR-149-5p & GGGAGTGAAGACACGGAG & MIMAT0000450 & 0.445735219 \\
\hline hsa-miR-484 & ATCGGGAGGGGACTGA & MIMAT0002174 & 0.442227863 \\
\hline hsa-miR-125a-5p & TCACAGGTTAAAGGGTCTC & MIMAT0000443 & 0.430950242 \\
\hline hsa-miR-503-5p & CTGCAGAACTGTTCCCGC & MIMAT0002874 & 0.41623705 \\
\hline hsa-miR-193b-3p & AGCGGGACTTTGAGGG & MIMAT0002819 & 0.400527954 \\
\hline hsa-miR-7-1-3p & TATGGCAGACTGTGATTTG & MIMAT0004553 & 0.385026073 \\
\hline hsa-miR-21-3p & ACAGCCCATCGACTG & MIMAT0004494 & 0.275550498 \\
\hline hsa-miR-29b-1-5p & TCTAAACCACCATATGAAACCAG & MIMAT0004514 & 0.154495867 \\
\hline
\end{tabular}

hsa, homo sapiens; miRNA or miR, microRNA.
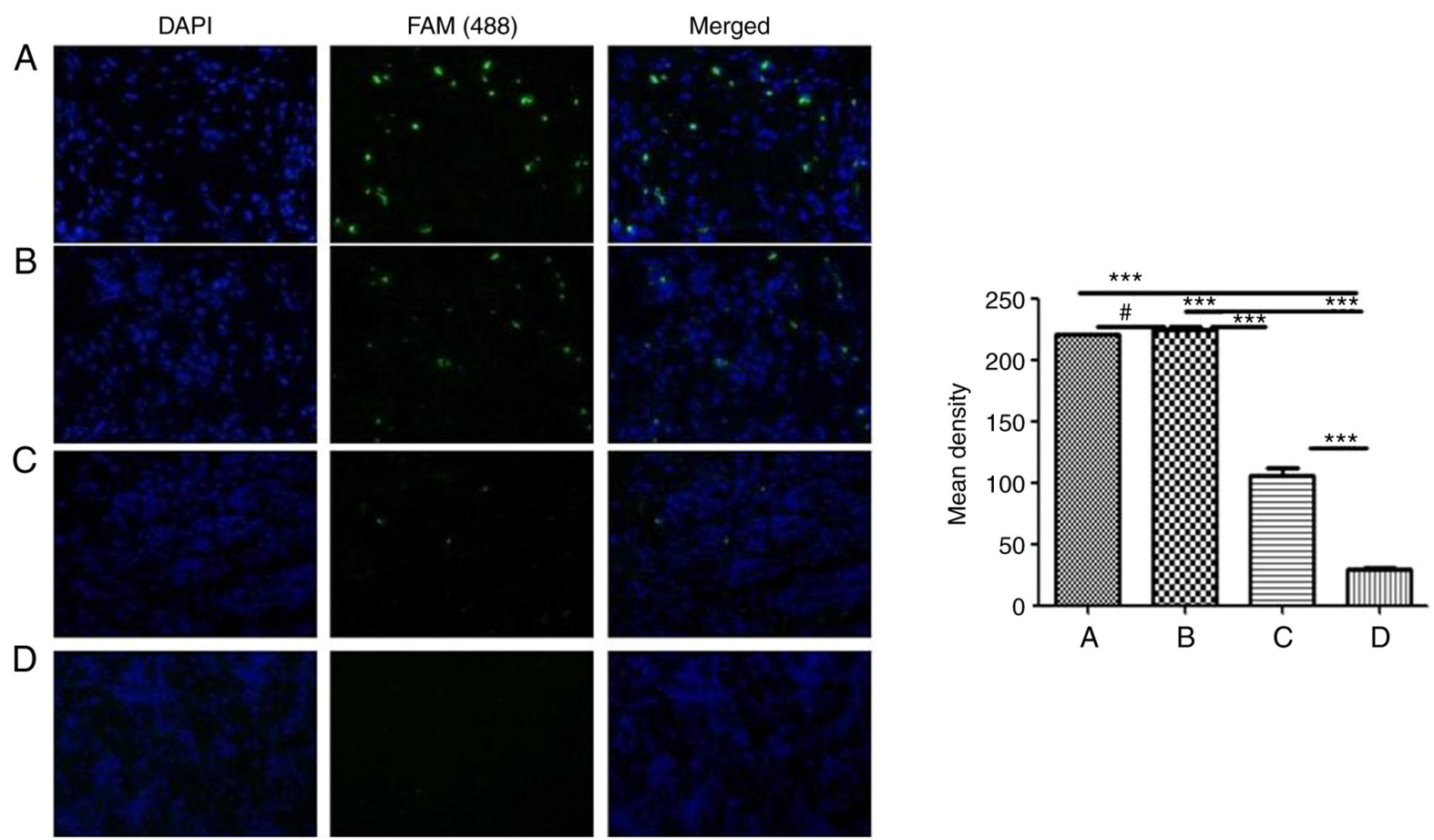

Figure 3. Expression of miRNA-7114 in different tissues of the lung $(\mathrm{n}=30)$ detected by fluorescence in situ hybridization. (A) Strong expression of miRNA-7114 in lung carcinoma tissue. (B) In lung atypical hyperplasia, the expression of miRNA-7114 was evident and the expression intensity and number of positive cells were not less than that of lung carcinoma tissue. (C) Para-lung carcinoma tissue revealed weak miRNA-7114 expression, significantly lower than the expression observed in lung carcinoma and atypical hyperplasia tissue. (D) Chronic inflammatory tissue of the lung was negative for miRNA-7114. ${ }^{\#} \mathrm{P}>0.05$ and ${ }^{* * *} \mathrm{P}<0.001$. miR, microRNA.

and forms DNA adducts; this is considered to be a key step in the initiation of lung cancer $(55,56)$. If the accumulation of benzopyrene-DNA adducts induced by cigarette smoking can be prevented, it may be possible to reduce the carcinogenic effect of benzopyrene. In the present study, there was significant formation of benzopyrene-DNA adducts in human BE 
Table III. Upregulated miRNA expression in human bronchial epithelial cells following EGCG treatment (EGCG+CSE vs. CSE).

\begin{tabular}{|c|c|c|c|}
\hline Systematic name & active_sequence & miRBase_accession_No & Fold change \\
\hline hsa-miR-1229-5p & CGCTCTCCCCCAA & MIMAT0022942 & 9.622524326 \\
\hline hsa-miR-1246 & CCTGCTCCAAAAATCC & MIMAT0005898 & 8.609823167 \\
\hline hsa-miR-1260a & TGGTGGCAGAGGTGG & MIMAT0005911 & 8.014158049 \\
\hline hsa-miR-1260b & ATGGTGGCAGTGGTG & MIMAT0015041 & 7.831567982 \\
\hline hsa-miR-1290 & TCCCTGATCCAAAAATCC & MIMAT0005880 & 6.888659175 \\
\hline hsa-miR-1973 & TATGCTACCTTTGCACG & MIMAT0009448 & 5.991243388 \\
\hline hsa-miR-198 & GAACCTATCTCСССТC & MIMAT0000228 & 5.868299699 \\
\hline hsa-miR-3135b & CACCACTGCACTCG & MIMAT0018985 & 5.285732155 \\
\hline hsa-miR-320c & АСССТСТСААСССАG & MIMAT0005793 & 5.078379085 \\
\hline hsa-miR-331-3p & TTCTAGGATAGGCCCAGGG & MIMAT0000760 & 4.69258682 \\
\hline hsa-miR-3663-3p & GCGCCCGGCCT & MIMAT0018085 & 4.148186871 \\
\hline hsa-miR-3679-5p & TCСССТTCССТGCC & MIMAT0018104 & 3.898141597 \\
\hline hsa-miR-4298 & СTGCCTCСТССТCC & MIMAT0016852 & 3.563938448 \\
\hline hsa-miR-4459 & СТССАССТССТССG & MIMAT0018981 & 3.006691394 \\
\hline hsa-miR-4466 & CCCCGCCGGCC & MIMAT0018993 & 2.973974082 \\
\hline hsa-miR-4485-3p & TTAGGGTACCGCGGC & MIMAT0019019 & 2.965321858 \\
\hline hsa-miR-4485-5p & TCACTGGGCAGGCG & MIMAT0032116 & 2.89697668 \\
\hline hsa-miR-4497 & GCCCAGCCGTCC & MIMAT0019032 & 2.842534905 \\
\hline hsa-miR-4530 & CGCTCCCGTCCTG & MIMAT0019069 & 2.833925499 \\
\hline hsa-miR-4685-5p & AАCСТTGCCCCACTC & MIMAT0019771 & 2.779881775 \\
\hline hsa-miR-4698 & TGGGGTCTTCCTCTAC & MIMAT0019793 & 2.628778688 \\
\hline hsa-miR-4741 & AGCCGACCCCTCC & MIMAT0019871 & 2.502211839 \\
\hline hsa-miR-4793-5p & ССTCTGCCCTGTGG & MIMAT0019965 & 2.495999429 \\
\hline hsa-miR-4800-5p & TCСТTCСТTCCTCGG & MIMAT0019978 & 2.410802371 \\
\hline hsa-miR-483-5p & СТСССТТСТТТССТС & MIMAT0004761 & 2.397856092 \\
\hline hsa-miR-5100 & AGAGGCACCGCTGG & MIMAT0022259 & 2.392975383 \\
\hline hsa-miR-5585-3p & ACCTGTAGTCCCAGCT & MIMAT0022286 & 2.309263021 \\
\hline hsa-miR-5787 & ACCTCCCCGCGC & MIMAT0023252 & 2.286325308 \\
\hline hsa-miR-6085 & TGTGCTCCCCCAGC & MIMAT0023710 & 2.23497638 \\
\hline hsa-miR-6510-5p & GACTCСТСТСТСТССC & MIMAT0025476 & 2.217240609 \\
\hline hsa-miR-6785-5p & CACCATCATCCACGC & MIMAT0027470 & 2.211828087 \\
\hline hsa-miR-6821-5p & CCCCGCCTCGAG & MIMAT0027542 & 2.177540381 \\
\hline hsa-miR-6867-5p & ТСССТТСТТССТСТАСА & MIMAT0027634 & 2.170855211 \\
\hline hsa-miR-6891-5p & ССССТСАТССССС & MIMAT0027682 & 2.139695303 \\
\hline hsa-miR-7107-5p & СССТТССТССТССС & MIMAT0028111 & 2.084862808 \\
\hline hsa-miR-7108-5p & CCACCCGCCTGC & MIMAT0028113 & 2.025528729 \\
\hline
\end{tabular}

hsa, homo sapiens; miRNA or miR, microRNA; EGCG, epigallocatechin-3-gallate; HBE, human bronchial epithelial.

Table IV. miRNA expression of HBE cells downregulated by EGCG treatment (EGCG+CSE vs. CSE).

\begin{tabular}{llrr}
\hline Systematic name & \multicolumn{1}{c}{ active_sequence } & miRBase_accession_No & Fold change \\
\hline hsa-miR-7110-5p & CTCTCTCTCCCCACA & MIMAT0028117 & 0.491007589 \\
hsa-miR-7114-5p & ACAGGCACCCCACT & MIMAT0028125 & 0.489623515 \\
hsa-miR-7150 & TACCTCTCCCCCTGC & MIMAT0028211 & 0.486650133 \\
hsa-miR-762 & GCTCGGCCCCGG & MIMAT0010313 & 0.481613982 \\
hsa-miR-7847-3p & GCCTCCTCCTCGTC & MIMAT0030422 & 0.424841654 \\
hsa-miR-8063 & AAGCCCCGACTCCT & MIMAT0030990 & 0.383320641 \\
\hline
\end{tabular}

hsa, homo sapiens; miRNA or miR, microRNA; EGCG, epigallocatechin-3-gallate; HBE, human bronchial epithelial. 

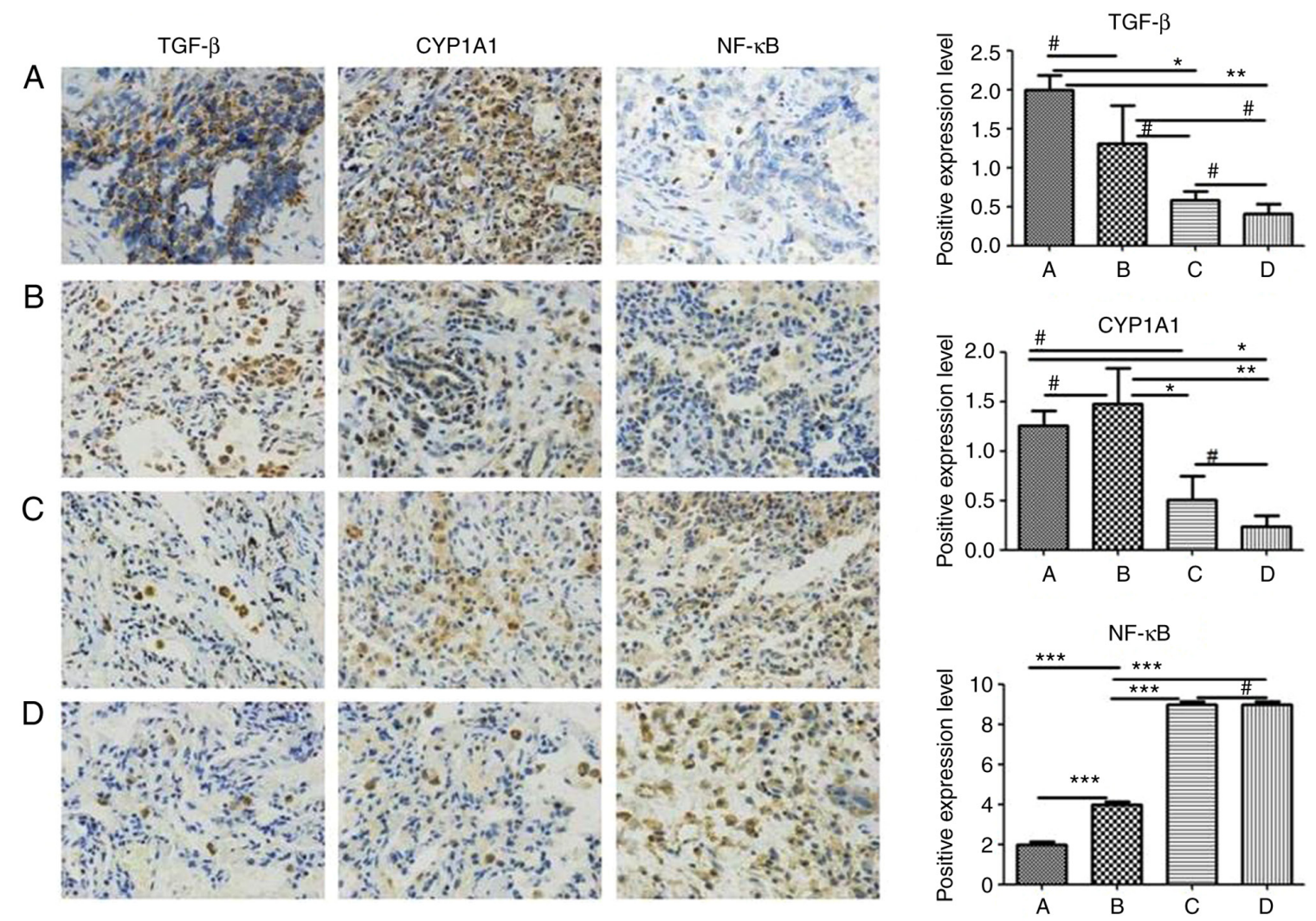

Figure 4. Expression of TGF- $\beta$, CYP1A1 and NF- $\mathrm{kB}$ in non-small cell lung carcinoma tissues. The samples were detected by immunohistochemistry and stained by DAB at a magnification of x100. The expression of TGF- $\beta$ and CYP1A1 in non-small cell lung carcinoma and lung atypical hyperplasia tissues was significantly higher than in para-carcinoma and chronic inflammatory tissues. Conversely, the expression of NF- $\mathrm{kB}$ in non-small cell carcinoma and in lung atypical hyperplasia tissues was significantly lower than in para-carcinoma and chronic inflammatory tissues. (A) In non-small cell lung carcinoma tissue, TGF- $\beta$ and CYP1A1 proteins were highly expressed, with NF- $\kappa$ B expressed at a low level. (B) In lung atypical hyperplasia tissue, TGF- $\beta$ and CYP1A1 proteins were strongly expressed but NF- $\mathrm{kB}$ was weakly expressed. (C) In para-lung carcinoma tissues, TGF- $\beta$ and CYP1A1 proteins were expressed at low levels, with NF- $\kappa B$ protein expressed at a high level. (D) In chronic inflammatory lung tissue, TGF- $\beta$ and CYP1A1 proteins were weakly expressed, while NF- $\kappa B$ was strongly expressed. ${ }^{*} \mathrm{P}>0.05,{ }^{*} \mathrm{P}<0.05,{ }^{* *} \mathrm{P}<0.01$ and ${ }^{* * *} \mathrm{P}<0.001$. TGF, transforming growth factor; NF- $\mathrm{k}$, nuclear factor- $\mathrm{\kappa B}$.
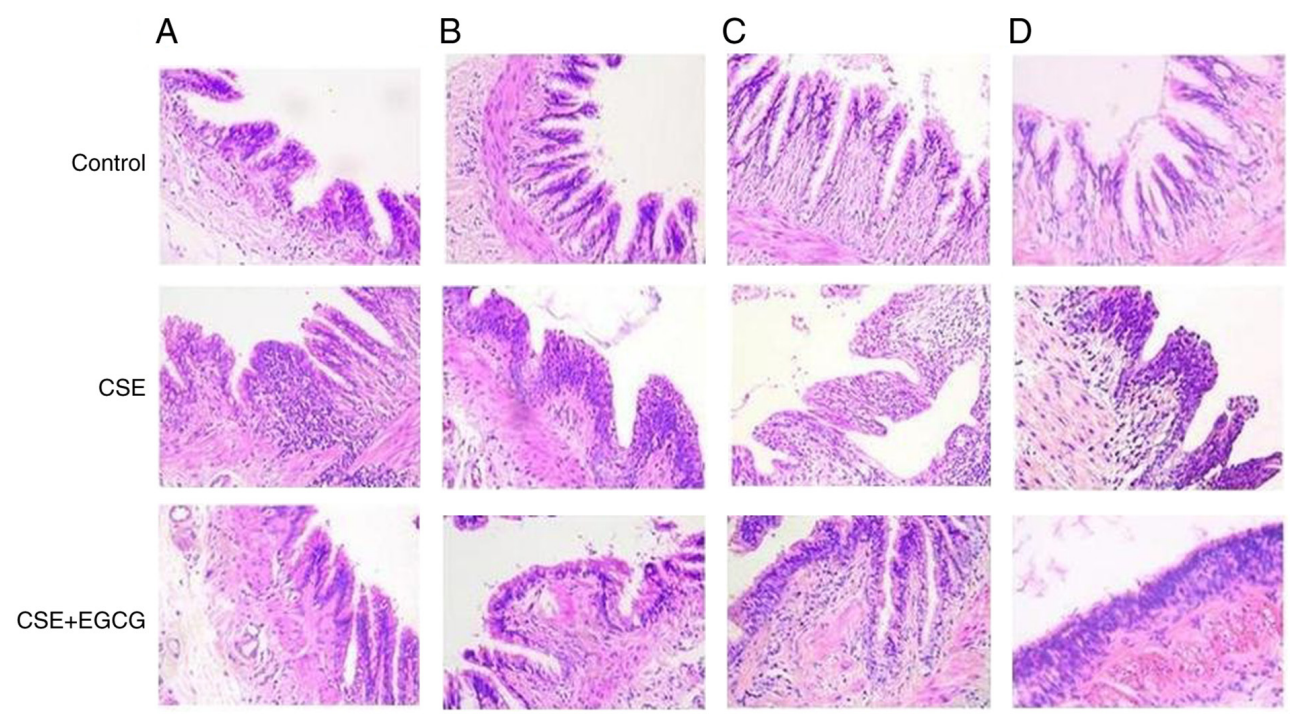

Figure 5. Rat broncho-epithelial lesions induced by CSE and the effect of EGCG. Hematoxylin and eosin staining at a magnification of x100. (A) At the end of the fourth week, the sub-bronchial epithelial tissue of rats in the CSE group revealed significant inflammatory cell infiltration; this response was markedly muted in the CSE+EGCG group, with the control group revealing healthy lungs. (B) Lung inflammation was still present in rats following eight weeks of CSE treatment with the development of BE cell hyperplasia. The level of inflammation was significantly reduced in the CSE+EGCG treatment group compared with the CSE group. The control group revealed no aberrancies. (C) After 12 weeks of CSE exposure, BE hyperplasia was marked in rats treated with CSE only, while it was not obvious in the CSE+EGCG group. Control lungs revealed no epithelial hyperplasia. (D) At the experimental end point of 16 weeks, $\mathrm{BE}$ hyperplasia was extensive in the lungs of rats treated with CSE only. There was evidence of papillary hyperplasia of the epithelium protruding into the bronchial cavity with large, dark nuclei of the focal epithelium. These lesions were markedly reduced in the CSE+EGCG treatment group. The control group revealed normal lung tissue. BE, bronchial epithelial; CSE, cigarette smoke extract; EGCG, epigallocatechin-3-gallate. 
A
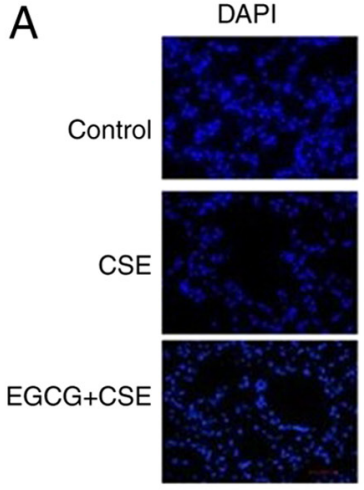

C

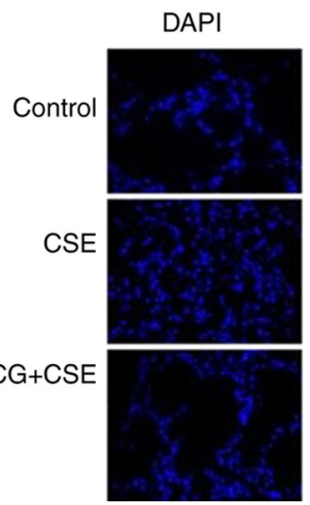

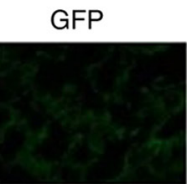
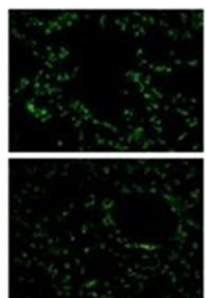

GFP
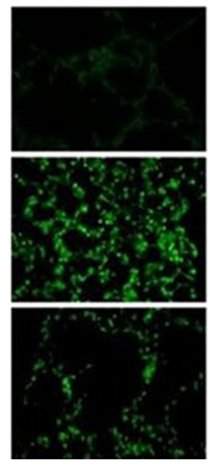

Merged
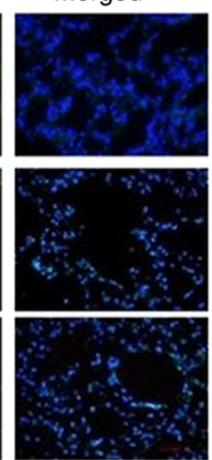

Merged

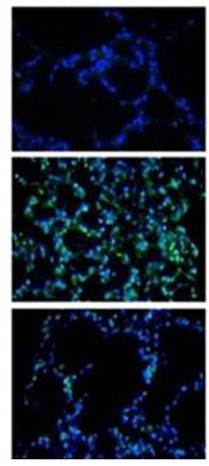

$\mathrm{B}$
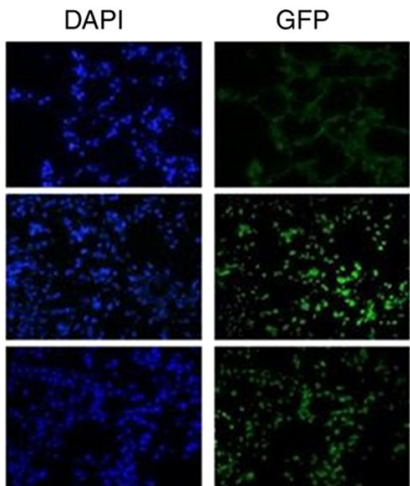

GFP

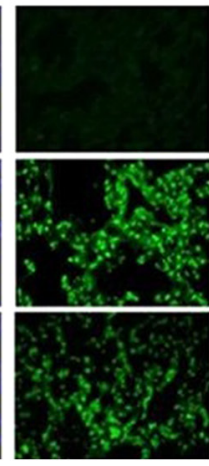

Merged
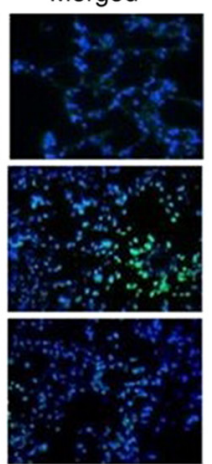

D

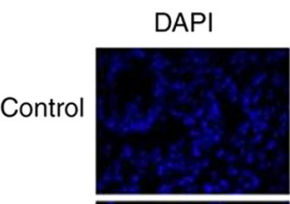

CSE

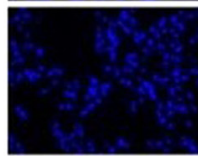

$E G C G+C S E$

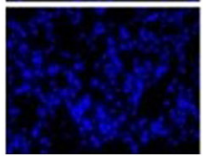

Merged

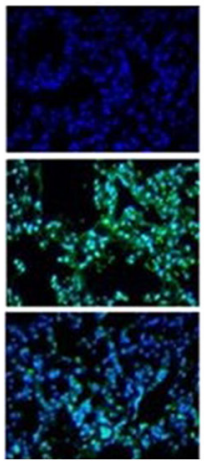

Figure 6. Pulmonary benzopyrene-DNA adducts in rats treated with CSE and EGCG+CSE, detected by immunofluorescence histochemistry. (A) After four weeks, there was weak fluorescence in the lungs of rats exposed to CSE, indicating the formation of benzopyrene DNA-adducts. The fluorescence levels were lower in the CSE+EGCG treatment group, while there was no fluorescence in the control group. (B) After eight weeks of CSE treatment, the level of fluorescence increased in the CSE only group, indicating an increase in the number of benzopyrene DNA-adducts. There was markedly lower fluorescence in the CSE+EGCG group. No aberrancies were observed in the control group. (C) After 12 weeks, fluorescence levels increased in the CSE only group, while EGCG intervention markedly reduced the formation of the DNA-adducts. The control group exhibited no fluorescence. (D) After 16 weeks, the fluorescence levels had further increased in the CSE only group lungs. It was markedly lower in the CSE+EGCG group. The control group remained normal. CSE, cigarette smoke extract; EGCG, epigallocatechin-3-gallate.
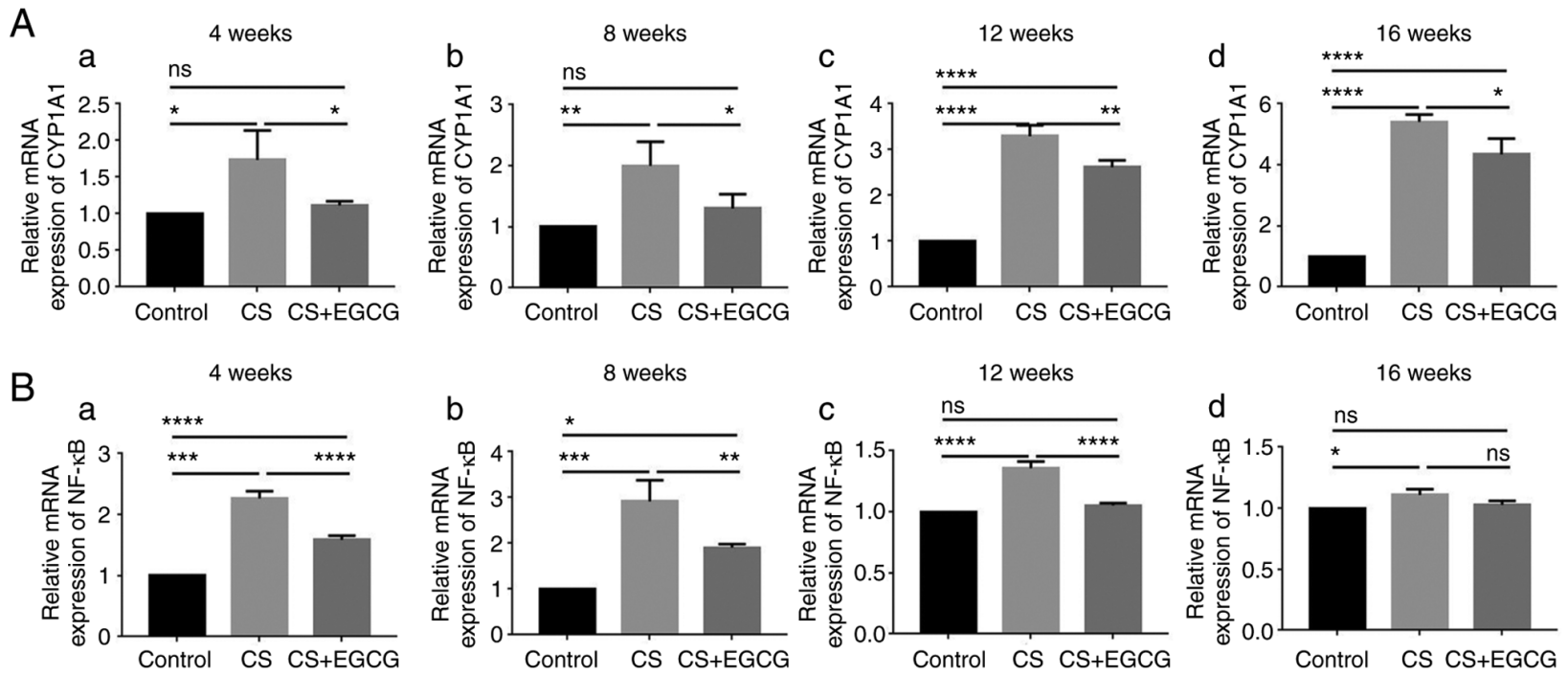

Figure 7. mRNA expression of target genes CYP1A1 and NF- $\kappa \mathrm{B}$ in rat lung tissues detected by reverse transcription-quantitative PCR. (A) The mRNA expression of target gene CYP1A1 in rat lung tissues: (a) Four weeks of treatment. CYP1A1 mRNA expression in rat lung tissue significantly increased with CS exposure. EGCG intervention significantly inhibited CYP1A1 mRNA overexpression. (b) Eight weeks of treatment. CYP1A1 mRNA expression was further increased in the lung tissue of rats treated with CS. EGCG intervention significantly inhibited CYP1A1 mRNA overexpression. (c) Twelve weeks of treatment. CYP1A1 mRNA expression increased in rat lung tissue following CS exposure. EGCG intervention significantly reduced cigarette-induced CYP1A1 mRNA overexpression. (d) Sixteen weeks of treatment. CYP1A1 mRNA reached its highest expression levels after 16 weeks of CS; this was significantly attenuated with EGCG treatment.

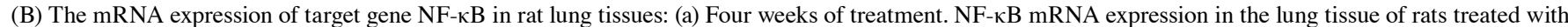
CS was significantly increased. EGCG significantly inhibited NF- $\kappa \mathrm{B}$ mRNA overexpression induced by cigarette smoking. (b) Eight weeks of treatment. NF- $\kappa \mathrm{B}$ mRNA expression was highest after eight weeks of CS exposure; this was significantly inhibited by EGCG intervention. (c) Twelve weeks of treatment. On the 12thweek of cigarette exposure, NF- $\mathrm{kB}$ mRNA levels had decreased; however, EGCG intervention still had slightly lower mRNA levels. (d) Sixteen weeks of treatment. NF- $\kappa \mathrm{B}$ expression in the lung tissues of rats in the $\mathrm{CS}$ treatment group was not significantly different from that in the $\mathrm{CS}+\mathrm{EGCG}$ treatment group. ${ }^{*} \mathrm{P}<0.05$,

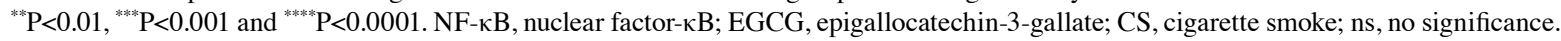


4
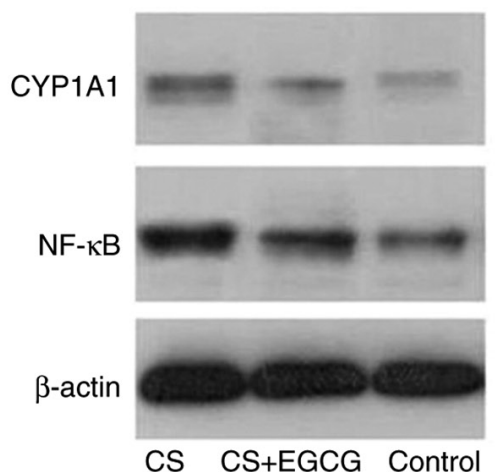

CS CS+EGCG Control
8
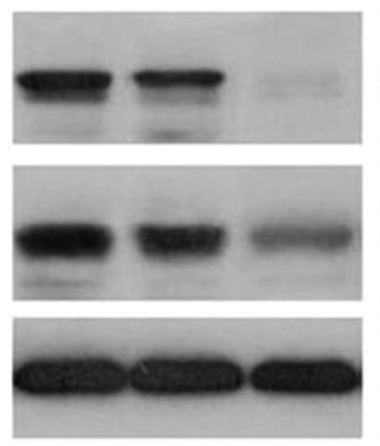

CS CS+EGCG Control
12
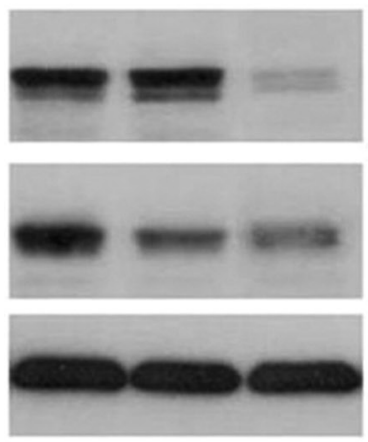

CS CS+EGCG Control
16

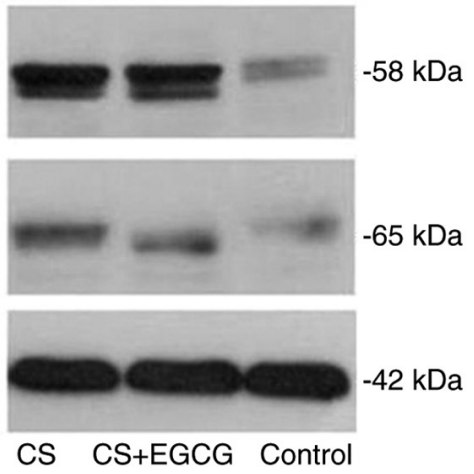

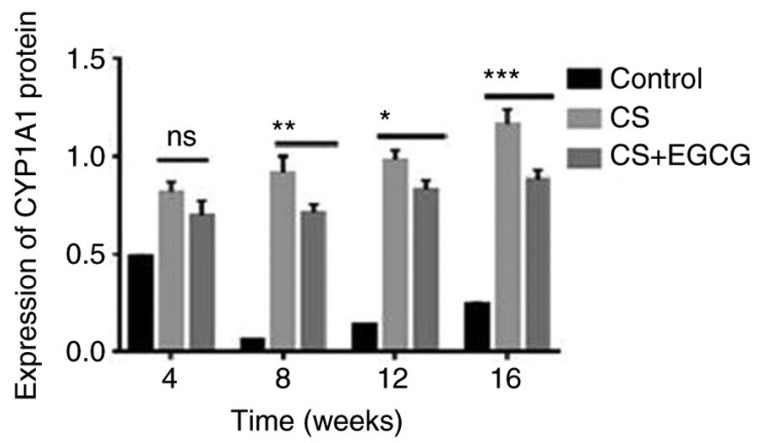

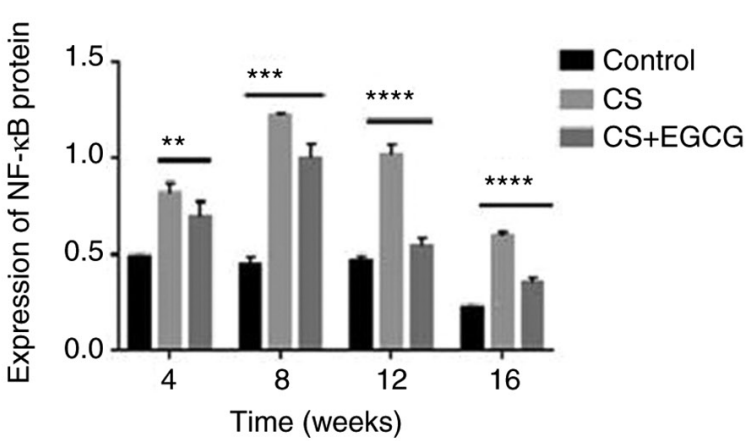

Figure 8. Protein expression of target genes CYP1A1 and NF- $\mathrm{KB}$ in rat lung tissues detected by western blotting. In the control group, the lung tissue of the rats revealed low expression of CYP1A1. After 4 weeks of CS, the expression of CYP1A1 protein in rat lung tissues increased. From week 8 to week 16, there was significant overexpression of CYP1A1 protein in the rat lungs exposed to CS. EGCG treatment significantly downregulated the overexpression of CYP1A1 protein in rat lung tissues induced by CS. NF- $\mathrm{kB}$ was weakly expressed in the lung tissue of control rats. Between weeks 4 and 12, CS increased the protein expression of NF- $\mathrm{KB}$ in rat lung tissue, while EGCG administration downregulated this expression. However, NF- $\mathrm{\kappa B}$ overexpression then decreased until the

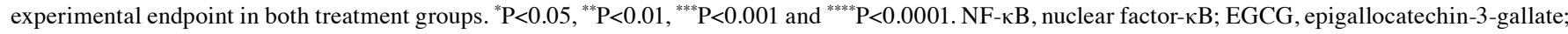
CS, cigarette smoke.

cells treated with CSE. These results indicated the presence of active benzopyrene in CS. Smoking increases the risk of cancer developing in the epithelial cells of the trachea (57). However, the present study has revealed that epithelial cells exposed to CS in combination with EGCG, had a significant reduction in the amount of benzopyrene-DNA adducts formed. These results provided direct evidence that the green tea extract is protective against the formation of potentially cancerous adducts. In further in vivo experiments, it was observed that significant bronchial inflammation developed in rats after 4 weeks of CS inhalation, which was accompanied by the detection of benzopyrene-DNA adducts. This inflammation led to the development of BE atypical hyperplasia and heteroplasms in these rats. Importantly, these precancerous lesions were significantly reduced by the consumption of water containing 0.3\% EGCG. Thus, it could be concluded that the green tea extract EGCG is protective against precancerous lesions and that EGCG interrupts a series of processes in the development of lung cancer, preventing carcinogenesis by mediating the damage caused by carcinogens found in CS.

Effects of EGCG on the expression of CYPIAl in the prevention of smoke-induced bronchial epithelial lesions. As above-mentioned, lung cancer is a chronic disease, with the malignant transformation of $\mathrm{BE}$ cells being a slow process. There are numerous genes (such as NLRP3, Nrf2, IL-1 $\beta$, caspase-1 and K-ras) involved in this transformation (58-60).
It has been proposed that EGCG may interact in a protective manner with these numerous genes (61). However, the number of genes which play a key role in BE cell carcinogenesis may be few. Therefore, it was crucial to identify these genes and whether they may be modulated by the green tea extract EGCG. For the most part, aberrant gene expression was related to changes caused by the developing malignancy and not the carcinogenesis itself. Moreover, the expression of various genes and the activation of signaling pathways are regulated by miRNAs. Molecular changes, such as the dysregulation of miRNA expression, have been linked to tobacco smoking in lung cancer (35). In the present study, in human epithelial cells, it was observed that several miRNAs had upregulated expression following CSE treatment, with multiple miRNAs also being downregulated. Not only did the use of EGCG as a therapeutic inhibit the upregulation of potentially cancerous miRNAs following CS exposure, it also upregulated novel miRNAs that may play a protective role. Not all of the target genes of these miRNAs are related to carcinogenesis, however there are several genes which have been previously linked to the development of lung cancer $(5,10,11,13,21,27)$. TGF- $\beta$, CYP1A1 and NF- $\kappa \mathrm{B}$ are all targets genes of these miRNAs; their expression may also be affected by the intervention of EGCG. TGF- $\beta$ and CYP1A1 were overexpressed in lung cancer tissues, while NF- $\kappa B$ was weakly expressed in atypical hyperplasia tissue and highly expressed in inflammatory tissues. It was indicated that the aberrant expression of TGF- $\beta$ and CYP1A1 was closely related 
to smoking-induced lung cancer, while the aberrant expression of NF- $\kappa \mathrm{B}$ may be more related to smoking-induced inflammation.

In the present study, rats exposed to CS had an initial bronchial/lung inflammatory response, followed by atypical proliferation and dysplasia of the bronchial epithelium. In the early inflammatory response to smoking, the expression of CYP1A1 and NF- $\kappa$ B was significantly upregulated; EGCG treatment significantly inhibited the overexpression of CYP1A1 and $\mathrm{NF}-\kappa \mathrm{B}$. In the later experimental stages, the expression of $\mathrm{NF}-\kappa \mathrm{B}$ in the lung tissue from rats in the experimental group was not significantly different to that of the tissue identified in the control. This result further supported the hypothesis that NF- $\mathrm{BB}$ expression may be more correlated with the initial inflammation of the lung, rather than the development of tumors. In the CS treatment experiment, the expression of CYP1A1 in the lung tissue of the smoke-exposed rats was high, gradually increasing throughout the experiment. EGCG treatment consistently inhibited the overexpression of CYP1A1 induced by smoking in rat lung tissues. These results indicated that the mechanism of smoking-induced BE carcinogenesis was most probably related to the aberrant expression of CYP1A1; EGCG may therefore block smoking-induced $\mathrm{BE}$ carcinogenesis by regulating the function of CYP1A1. Compared with CYP1A1, the aberrant expression of $\mathrm{NF}-\kappa \mathrm{B}$ may be more closely associated with inflammation rather than with the carcinogenesis of BE cells.

CYP1A1 encodes the cytochrome P450 1A1. This protein is a major enzyme that activates polycyclic aromatic (pahs) carcinogens. Activated CYP1A1 can turn organic substances such as polyaromatic hydrocarbons into cytotoxins and other carcinogens, increasing the risk of cancer (62). Tobacco contains a large amount of benzopyrene, which is inhaled into the lungs when smoking. Benzopyrene is firstly epoxidized by CYP1A1, which is then hydrolyzed by epoxide hydrolase to form a dihydroxyl compound. This is then oxidized by CYP1A1 to form a diol epoxide. Diol epoxides have significant carcinogenic and mutagenic effects. These reactive metabolites produce DNA adducts, resulting in DNA mutations, gene expression profile alterations and tumorigenesis (62). Inhibition of CYP1A1-catalyzed benzopyrene metabolism may reduce the risk of smoking-induced lung cancer. In this in vivo experiment, it was observed that EGCG could inhibit the overexpression of CYP1A1 induced by smoking exposure. This therefore inhibits the metabolic mechanism of DNA adducts involving CYP1A1; subsequently preventing the development of atypical hyperplasia and heterogeneous precancerous lesions of bronchial epithelium. In addition to smoking, cooking, air pollution, automobile exhaust fumes and numerous other environmental sources may produce benzopyrene (62-65). There are still numerous opportunities for people to be exposed to environmental benzopyrene. Drinking green tea is therefore recommended as it is rich in EGCG which will inhibit the development of disease associated with benzopyrene exposure.

\section{Acknowledgements}

The authors would like to thank the staff of the Laboratory of Respiratory Medicine and the Department of Pathology at Xiangya Hospital affiliated to the Central South University, for their support.

\section{Funding}

The present study was supported by the National Key R\&D Program of China (grant no. 2016YFC1303800) and the Natural Science Foundation of Hunan Province (grant no. 2021JJ31062).

\section{Availability of data and materials}

All data generated or analyzed during this study are available from the corresponding author on reasonable request.

\section{Authors' contributions}

All of the authors made a significant contribution to the conception, study design, execution, acquisition of data, analysis. QG, NC and FC confirmed the authenticity of all the raw data. Moreover, QG presided over the project design, experiment execution, data acquisition and analysis, as well as paper writing and revision. FC was in charge of the in vivo experiment. NC performed the in vitro experiment and bioinformatics analysis. JW was responsible for the acquisition and analysis of histopathological data. ZL and XD participated in the data acquisition, sorting and analysis. All of the authors provided final approval of the version to be published and agree to be accountable for all aspects of the work.

\section{Ethics approval and consent to participate}

This research protocol was approved by the Medical Ethics Committee of Xiangya Hospital of Central South University (approval no. 201703133) and all patients provided written informed consent before surgery. All of the animals were treated humanely and in compliance with the Animal Welfare Act of America. The experiment was approved by the Ethics Department of Xiangya Hospital, Central South University (Changsha, China).

\section{Patient consent for publication}

Not applicable.

\section{Competing interests}

The authors declare that they have no competing interests.

\section{References}

1. Tu CY, Cheng FJ, Chen CM, Wang SL, Hsiao YC, Chen $\mathrm{CH}$, Hsia TC, He YH, Wang BW, Hsieh IS, et al: Cigarette smoke enhances oncogene addiction to c-MET and desensitizes EGFR-expressing non-small cell lung cancer to EGFR TKIs. Mol Oncol 12: 705-723, 2018

2. Raja R, Sahasrabuddhe NA, Radhakrishnan A, Syed N, Solanki HS, Puttamallesh VN, Balaji SA, Nanjappa V, Datta KK, Babu N, et al: Chronic exposure to cigarette smoke leads to activation of p21 (RAC1)-activated kinase 6 (PAK6) in non-small cell lung cancer cells. Oncotarget 7: 61229-61245, 2016.

3. Thai P, Statt S, Chen CH, Liang E, Campbell C and Wu R: Characterization of a novel long noncoding RNA, SCAL1, induced by cigarette smoke and elevated in lung cancer cell lines. Am J Respir Cell Mol Biol 49: 204-211, 2013.

4. Billatos E, Faiz A, Gesthalter Y, LeClerc A, Alekseyev YO, Xiao X, Liu G, Ten Hacken NHT, Heijink IH, Timens W, et al: Impact of acute exposure to cigarette smoke on airway gene expression. Physiol Genomics 50: 705-713, 2018. 
5. Gu Q, Hu C, Chen $\mathrm{N}$ and $\mathrm{Qu} \mathrm{J}$ : A comparison between lung carcinoma and a subcutaneous malignant tumor induced in rats by a 3,4-benzopyrene injection. Int J Clin Exp Pathol 11: 3934-3942, 2018.

6. Sá VK, Rocha TP, Moreira A, Soares FA, Takagaki T, Carvalho L, Nicholson AG and Capelozzi VL: Hyaluronidases and hyaluronan synthases expression is inversely correlated with malignancy in lung/bronchial pre-neoplastic and neoplastic lesions, affecting prognosis. Braz J Med Biol Res 48: 1039-1047, 2015.

7. Rushing BR and Selim MI: Aflatoxin B1: A review on metabolism, toxicity, occurrence in food, occupational exposure, and detoxification methods. Food Chem Toxicol 124: 81-100, 2019.

8. Gavish M, Cohen S and Nagler R: Cigarette smoke effects on TSPO and VDAC expression in a cellular lung cancer model. Eur J Cancer Prev 25: 361-367, 2016.

9. Nagler R, Cohen S and Gavish M: The effect of cigarette smoke on the translocator protein (TSPO) in cultured lung cancer cells J Cell Biochem 116: 2786-2792, 2015.

10. Meng X, Meng C, Yang B, Zhao L, Sun X, Su Y, Liu H, Fan F, Liu X and Jia L: AP-2 $\alpha$ downregulation by cigarette smoke condensate is counteracted by p53 in human lung cancer cells. Int J Mol Med 34: 1094-1100, 2014.

11. Filosto S, Becker CR and Goldkorn T: Cigarette smoke induces aberrant EGF receptor activation that mediates lung cancer development and resistance to tyrosine kinase inhibitors. Mol Cancer Ther 11: 795-804, 2012.

12. Faiz A, Heijink IH, Vermeulen CJ, Guryev V, van den Berge M, Nawijn MC and Pouwels SD: Cigarette smoke exposure decreases CFLAR expression in the bronchial epithelium, augmenting susceptibility for lung epithelial cell death and DAMP release. Sci Rep 8: 12426, 2018

13. Gu Q, Hu C, Chen Q and Xia Y: Tea polyphenols prevent lung from preneoplastic lesions and effect p53 and bcl-2 gene expression in rat lung tissues. Int J Clin Exp Pathol 6: 1523-1531, 2013.

14. Sundar IK and Rahman I: Gene expression profiling of epigenetic chromatin modification enzymes and histone marks by cigarette smoke: Implications for COPD and lung cancer. Am J Physiol Lung Cell Mol Physiol 311: L1245-L1258, 2016.

15. Hayakawa S, Ohishi T, Miyoshi N, Oishi Y, Nakamura Y and Isemura M: Anti-cancer effects of green tea epigallocatchin-3-gallate and coffee chlorogenic acid. Molecules 25: $4553,2020$.

16. Singh BN, Shankar S and Srivastava RK: Green tea catechin, epigallocatechin-3-gallate (EGCG): Mechanisms, perspectives and clinical applications. Biochem Pharmacol 82: 1807-1821, 2011.

17. Zhang L, Chen W, Tu G, Chen X, Lu Y, Wu L and Zheng D Enhanced chemotherapeutic efficacy of PLGA-encapsulated epigallocatechin gallate (EGCG) against human lung cancer. Int J Nanomedicine 15: 4417-4429, 2020.

18. Tang N, Wu Y, Zhou B, Wang B and Yu R: Green tea, black tea consumption and risk of lung cancer: A meta-analysis. Lung Cancer 65: 274-283, 2009.

19. Fritz H, Seely D, Kennedy DA, Fernandes R, Cooley K and Fergusson D: Green tea and lung cancer: A systematic review. Integr Cancer Ther 12: 7-24, 2013.

20. Lu Y, Yao R, Yan Y, Wang Y, Hara Y, Lubet RA and You M: A gene expression signature that can predict green tea exposure and chemopreventive efficacy of lung cancer in mice. Cancer Res 66 : 1956-1963, 2006.

21. Gu Q, Hu C, Chen Q, Xia Y, Feng J and Yang H: Development of a rat model by 3,4-benzopyrene intra-pulmonary injection and evaluation of the effect of green tea drinking on p53 and bcl-2 expression in lung carcinoma. Cancer Detect Prev 32: 444-451, 2009.

22. Zhou H, Chen JX, Yang CS, Yang MQ, Deng Y and Wang H: Gene regulation mediated by microRNAs in response to green tea polyphenol EGCG in mouse lung cancer. BMC Genomics 15 (Suppl 11): S3, 2014

23. Huang J, Chen S, Shi Y, Li CH, Wang XJ, Li FJ, Wang CH, Meng QH, Zhong JN, Liu M and Wang ZM: Epigallocatechin gallate from green tea exhibits potent anticancer effects in A-549 non-small lung cancer cells by inducing apoptosis, cell cycle arrest and inhibition of cell migration. J BUON 22: 1422-1427, 2017.

24. Oya Y, Mondal A, Rawangkan A, Umsumarng S, Iida K, Watanabe T, Kanno M, Suzuki K, Li Z, Kagechika H, et al: Down-regulation of histone deacetylase $4,-5$ and -6 as a mechanism of synergistic enhancement of apoptosis in human lung cancer cells treated with the combination of a synthetic retinoid, Am80 and green tea catechin. J Nutr Biochem 42: 7-16, 2017.
25. Milligan SA, Burke P, Coleman DT, Bigelow RL, Steffan JJ, Carroll JL, Williams BJ and Cardelli JA: The green tea polyphenol EGCG potentiates the antiproliferative activity of c-Met and epidermal growth factor receptor inhibitors in non-small cell lung cancer cells. Clin Cancer Res 15: 4885-4894, 2009.

26. Li M, Li JJ, Gu QH, An J, Cao LM, Yang HP and Hu CP: EGCG induces lung cancer A549 cell apoptosis by regulating $\mathrm{Ku} 70$ acetylation. Oncol Rep 35: 2339-2347, 2016.

27. Zhang L, Xie J, Gan R, Wu Z, Luo H, Chen X, Lu Y, Wu L and Zheng D: Synergistic inhibition of lung cancer cells by EGCG and NF- $\kappa B$ inhibitor BAY11-7082. J Cancer 10: 6543-6556, 2019.

28. Jiang P, Xu C, Zhang P, Ren J, Mageed F, Wu X, Chen L, Zeb F, Feng Q and Li S: Epigallocatechin-3-gallate inhibits self-renewal ability of lung cancer stem-like cells through inhibition of CLOCK. Int J Mol Med 46: 2216-2224, 2020.

29. Deng YT and Lin JK: EGCG inhibits the invasion of highly invasive CL1-5 lung cancer cells through suppressing MMP-2 expression via JNK signaling and induces G2/M arrest. J Agric Food Chem 59: 13318-13327, 2011

30. Gu JJ, Qiao KS, Sun P, Chen P and Li Q: Study of EGCG induced apoptosis in lung cancer cells by inhibiting PI3K/Akt signaling pathway. Eur Rev Med Pharmacol Sci 22: 4557-4563, 2018.

31. Yu C, Jiao Y, Xue J, Zhang Q, Yang H, Xing L, Chen G, Wu J, Zhang S, Zhu W and Cao J: Metformin sensitizes non-small cell lung cancer cells to an epigallocatechin-3-gallate (EGCG) treatment by suppressing the Nrf2/HO-1 signaling pathway. Int J Biol Sci 13: 1560-1569, 2017

32. Zhu J, Jiang Y, Yang X, Wang S, Xie C, Li X, Li Y, Chen Y, Wang $\mathrm{X}$, Meng $\mathrm{Y}$, et al: Wnt $/ \beta$-catenin pathway mediates (-)-Epigallocatechin-3-gallate (EGCG) inhibition of lung cancer stem cells. Biochem Biophys Res Commun 482: 15-21, 2017.

33. Wei R, Wirkus J, Yang Z, Machuca J, Esparza Y and Mackenzie GG: EGCG sensitizes chemotherapeutic-induced cytotoxicity by targeting the ERK pathway in multiple cancer cell lines. Arch Biochem Biophys 692: 108546, 2020.

34. Chen A, Jiang P, Zeb F, Wu X, Xu C, Chen L and Feng Q: EGCG regulates CTR1 expression through its pro-oxidative property in non-small-cell lung cancer cells. J Cell Physiol 235: 7970-7981, 2020.

35. Doukas SG, Vageli DP, Lazopoulos G, Spandidos DA, Sasaki CT and Tsatsakis A: The effect of NNK, a tobacco smoke carcinogen, on the miRNA and mismatch dna repair expression profiles in lung and head and neck squamous cancer cells. Cells 9: 1031, 2020.

36. Hu DL, Wang G, Yu J, Zhang LH, Huang YF, Wang D and Zhou HH: Epigallocatechin-3-gallate modulates long non-coding RNA and mRNA expression profiles in lung cancer cells. Mol Med Rep 19: 1509-1520, 2019.

37. Bhardwaj V and Mandal AKA: Next-generation sequencing reveals the role of epigallocatechin-3-gallate in regulating putative novel and known microRNAs which target the MAPK pathway in non-small-cell lung cancer a549 cells. Molecules 24: 368, 2019.

38. Chen Y, Pan Y, Ji Y, Sheng L and Du X: Network analysis of differentially expressed smoking-associated mRNAs, lncRNAs and miRNAs reveals key regulators in smoking-associated lung cancer. Exp Ther Med 16: 4991-5002, 2018.

39. Torkashvand J, Farzadkia M, Sobhi HR and Esrafili A: Littered cigarette butt as a well-known hazardous waste: A comprehensive systematic review. J Hazard Mater 383: 121242, 2020.

40. Hecht SS: Approaches to chemoprevention of lung cancer based on carcinogens in tobacco smoke. Environ Health Perspect 105 (Suppl 4): S955-S963, 1997.

41. Hoffmann D, Rivenson A, Chung FL and Hecht SS: Nicotine-derived N-nitrosamines (TSNA) and their relevance in tobacco carcinogenesis. Crit Rev Toxicol 21: 305-311, 1991

42. Li GX, Chen YK, Hou Z, Xiao H, Jin H, Lu G, Lee MJ, Liu B, Guan F, Yang Z, et al: Pro-oxidative activities and dose-response relationship of (-)-epigallocatechin-3-gallate in the inhibition of lung cancer cell growth: A comparative study in vivo and in vitro. Carcinogenesis 31: 902-910, 2010.

43. Thomassen DG, Chen BT, Mauderly JL, Johnson NF and Griffith WC: Inhaled cigarette smoke induces preneoplastic changes in rat tracheal epithelial cells. Carcinogenesis 10: 2359-2361, 1989

44. Bjermer L, Cai Y, Nilsson K, Hellström S and Henriksson R: Tobacco smoke exposure suppresses radiation-induced inflammation in the lung: A study of bronchoalveolar lavage and ultrastructural morphology in the rat. Eur Respir J 6: 1173-1180, 1993. 
45. Xue Y, Harris E, Wang W and Baybutt RC: Vitamin A depletion induced by cigarette smoke is associated with an increase in lung cancer-related markers in rats. J Biomed Sci 22: 84, 2015.

46. Livak KJ and Schmittgen TD: Analysis of relative gene expression data using real-time quantitative PCR and the 2(-Delta Delta C(T)) method. Methods 25: 402-408, 2001.

47. Yuan C, Xiang L, Bai R, Cao K, Gao Y, Jiang X, Zhang N, Gong Y and Xie C: MiR-195 restrains lung adenocarcinoma by regulating $\mathrm{CD}^{+} \mathrm{T}$ cell activation via the $\mathrm{CCDC} 88 \mathrm{C} / \mathrm{Wnt}$ signaling pathway: A study based on the cancer genome atlas (TCGA), gene expression omnibus (GEO) and bioinformatic analysis. Ann Transl Med 7: 263, 2019.

48. Chen Y and Wang X: miRDB: An online database for prediction of functional microRNA targets. Nucleic Acids Res 48D: D127-D131, 2020.

49. Vlachos IS, Zagganas K, Paraskevopoulou MD, Georgakilas G, Karagkouni D, Vergoulis T, Dalamagas T and Hatzigeorgiou AG: DIANA-miRPath v3.0: Deciphering microRNA function with experimental support. Nucleic Acids Res 43W: W460-W466, 2015.

50. Freis A, Keller A, Ludwig N, Meese E, Jauckus J, Rehnitz J, Capp E, Strowitzki T and GermeyerA: Altered miRNA-profile dependent on ART outcome in early pregnancy targets Wnt-pathway. Reproduction 154: 799-805, 2017.

51. Wang C, Wu R, Sargsyan D, Zheng M, Li S, Yin R, Su S, Raskin I and Kong AN: CpG methyl-seq and RNA-seq epigenomic and transcriptomic studies on the preventive effects of Moringa isothiocyanate in mouse epidermal JB6 cells induced by the tumor promoter TPA. J Nutr Biochem 68: 69-78, 2019.

52. Zhao X, Liang M, Li X, Qiu X and Cui L: Identification of key genes and pathways associated with osteogenic differentiation of adipose stem cells. J Cell Physiol 233: 9777-9785, 2018.

53. Heinrich U, Muhle H, Takenaka S, Ernst H, Fuhst R, Mohr U, Pott $\mathrm{F}$ and Stöber W: Chronic effects on the respiratory tract of hamsters, mice and rats after long-term inhalation of high concentrations of filtered and unfiltered diesel engine emissions. J Appl Toxicol 6: 383-395, 1986.

54. Melnick RL, Huff JE, Roycroft JH, Chou BJ and Miller RA: Inhalation toxicology and carcinogenicity of 1,3-butadiene in B6C3F1 mice following 65 weeks of exposure. Environ Health Perspect 86: 27-36, 1990 .

55. Ceppi M, Munnia A, Cellai F, Bruzzone M and Peluso MEM: Linking the generation of DNA adducts to lung cancer. Toxicology 390: 160-166, 2017.

56. Munnia A, Giese RW, Polvani S, Galli A, Cellai F and Peluso MEM Bulky DNA adducts, tobacco smoking, genetic susceptibility, and lung cancer risk. Adv Clin Chem 81: 231-277, 2017.
57. Avino P, Scungio M, Stabile L, Cortellessa G, Buonanno G and Manigrasso M: Second-hand aerosol from tobacco and electronic cigarettes: Evaluation of the smoker emission rates and doses and lung cancer risk of passive smokers and vapers. Sci Total Environ 642: 137-147, 2018.

58. Duan S, Wang N, Huang L, Shao H, Zhang P, Wang W, Wu Y, Wang J, Liu H, Zhang Q and Feng F: NLRP3 inflammasome activation involved in LPS and coal tar pitch extract-induced malignant transformation of human bronchial epithelial cells. Environ Toxicol 34: 585-593, 2019.

59. VazM,Hwang SY,Kagiampakis I, Phallen J,Patil A,O'Hagan HM, Murphy L, Zahnow CA, Gabrielson E, Velculescu VE, et al: Chronic cigarette smoke-induced epigenomic changes precede sensitization of bronchial epithelial cells to single-step transformation by KRAS mutations. Cancer Cell 32: 360-376.e6, 2017.

60. Chen C, Jiang X, Gu S and Zhang Z: MicroRNA-155 regulates arsenite-induced malignant transformation by targeting Nrf2-mediated oxidative damage in human bronchial epithelial cells. Toxicol Lett 278: 38-47, 2017.

61. Fujiki H, Watanabe T, Sueoka E, Rawangkan A and Suganuma M: Cancer prevention with green tea and its principal constituent, EGCG: From early investigations to current focus on human cancer stem cells. Mol Cells 41: 73-82, 2018.

62. Moorthy B, Chu C and Carlin DJ: Polycyclic aromatic hydrocarbons: From metabolism to lung cancer. Toxicol Sci 145: 5-15, 2015.

63. Lawther PJ and Waller RE: Coal fires, industrial emissions and motor vehicles as sources of environmental carcinogens. IARC Sci Publ 6: 27-40, 1976

64. Perera F: Carcinogenicity of airborne fine particulate benzo(a) pyrene: An appraisal of the evidence and the need for control. Environ Health Perspect 42: 163-185, 1981.

65. Knize MG, Salmon CP, Pais P and Felton JS: Food heating and the formation of heterocyclic aromatic amine and polycyclic aromatic hydrocarbon mutagens/carcinogens. Adv Exp Med Biol 459: 179-193, 1999.

This work is licensed under a Creative Commons Attribution-NonCommercial-NoDerivatives 4.0 International (CC BY-NC-ND 4.0) License. 